\title{
SPECIAL SELECTION: BROWN FAT
}

\section{The brain and brown fat}

\author{
Cristina Contreras ${ }^{1,2}$, Francisco Gonzalez ${ }^{3,4}$, Johan Fern $\varnothing^{5}$, Carlos Diéguez ${ }^{1,2}$, Kamal Rahmouni ${ }^{6,7}$, \\ Rubén Nogueiras ${ }^{1,2} \&$ Miguel López ${ }^{1,2}$
}

${ }^{1}$ Department of Physiology, CIMUS, University of Santiago de Compostela-Instituto de Investigación Sanitaria, Santiago de Compostela, 15782, Spain, ${ }^{2}$ CIBER Fisiopatología de la Obesidad y Nutrición (CIBERobn), Santiago de Compostela, 15706, Spain, ${ }^{3}$ Department of Surgery, CIMUS, University of Santiago de Compostela-Instituto de Investigacion Sanitaria, Santiago de Compostela, 15782, Spain, ${ }^{4}$ Service of Ophthalmology, Complejo Hospitalario Universitario de Santiago de Compostela, Santiago de Compostela 15706, Spain, ${ }^{5}$ Department of Clinical Science, K.G. Jebsen Center for Diabetes Research, University of Bergen, Bergen, Norway, ${ }^{6}$ Department of Pharmacology, University of lowa, lowa City, IA 52242, USA, and ${ }^{7}$ Department of Internal Medicine, University of lowa, lowa City, IA 52242, USA

Brown adipose tissue (BAT) is a specialized organ responsible for thermogenesis, a process required for maintaining body temperature. BAT is regulated by the sympathetic nervous system (SNS), which activates lipolysis and mitochondrial uncoupling in brown adipocytes. For many years, BAT was considered to be important only in small mammals and newborn humans, but recent data have shown that BAT is also functional in adult humans. On the basis of this evidence, extensive research has been focused on BAT function, where new molecules, such as irisin and bone morphogenetic proteins, particularly BMP7 and BMP8B, as well as novel central factors and new regulatory mechanisms, such as orexins and the canonical ventomedial nucleus of the hypothalamus (VMH) AMPactivated protein kinase (AMPK)-SNS-BAT axis, have been discovered and emerged as potential drug targets to combat obesity. In this review we provide an overview of the complex central regulation of BAT and how different neuronal cell populations co-ordinately work to maintain energy homeostasis.

Key words: AMPK, $\beta$-adrenoreceptors, brown adipose tissue (BAT), hypothalamus, obesity, orexins, sympathetic nervous system (SNS), thermogenesis, thyroid hormone, uncoupling protein 1 (UCP1)

\section{Brown adipose tissue is a thermogenic machine}

Brown adipose tissue (BAT) is a special class of adipose tissue responsible for energy and dissipation, being the most important organ for non-shivering thermogenesis (NST) (1-10). Morphologically, BAT is clearly distinguishable from white adipose tissue (WAT). In particular, brown adipocytes show polygonal shape with multilocular lipid droplets, many large mitochondria, and are richly innervated by sympathetic nerve efferent fibers $(2,5,8,11,12)$, which ensure central control of thermogenesis. WAT, on the other hand, is the primary fat storage organ in the

\section{Key messages}

- Brown adipose tissue-induced thermogenesis is regulated by the central nervous system.

- Understanding the regulation of brown adipose tissue by the brain could provide new targets for the treatment of obesity and related metabolic disorders.

body and consists of unilocular adipocytes with a large lipid droplet for storage of excess calories when energy intake exceeds energy expenditure. Moreover, BAT is highly vascularized to allow the dissipation of generated heat (13), whereas WAT has evolutionarily enabled animals to survive for longer periods without meals, storing energy, mainly as triglycerides, and releasing fatty acids during fasting periods. Despite some initial controversies it is now accepted that brown adipocytes have a developmental origin that largely differs from that of the white adipocytes, as shown by the finding that even before differentiation brown and white fat cells express different genes (14-16).

Recently, evidence for a second type of brown adipocyte has been reported in both rodents and humans. It was found that brown fat cells may appear after thermogenic stimuli at anatomical sites corresponding to WAT. These beige or brite (brown in white) adipocytes derive from precursor cells different from those in classical BAT and are closer to the white adipocyte's cell lineage (17-21). Despite the fact that the cell origin and anatomical placement are different from BAT, this new lineage has all the morphological and molecular characteristics of classical brown adipocytes present in BAT depots and acts as true thermogenic brown adipocytes $(15,22,23)$. However, the thermogenic

Correspondence: Cristina Contreras PhD., and Miguel López, PhD., Department of Physiology, NeurObesity Group, CIMUS, University of Santiago de Compostela-Instituto de Investigación Sanitaria, Santiago de Compostela, 15782, Spain. + 0034881815418 (CC); + 0034881815420 (ML). Fax: + 34 881815403.E-mail: cristina.contreras@usc.es; m.lopez@usc.es

(c) 2015 The Author(s). Published by Taylor \& Francis. This is an Open Access article distributed under the terms of the Creative Commons AttributionNonCommercial-NoDerivs License (http://creativecommons.org/licenses/by-nc-nd/4.0/), which permits non-commercial re-use, distribution, and reproduction in any medium, provided the original work is properly cited, and is not altered, transformed, or built upon in any way. 
capacity of beige/brite cells in vivo is much lower compared to brown adipocytes (23-26).

\section{Thermogenic processes in brown adipocytes}

Since the 1970s, BAT has been recognized as the main NST organ. Thermogenesis is facilitated via uncoupling of mitochondrial respiration from ATP production, mediated by uncoupling protein 1 (UCP1), also called thermogenin, which is located in the inner mitochondrial membrane $(2,5,12,27)$. Using electron transport from the oxidation of fatty acids as substrate, UCP1 allows the free movement of protons back across the mitochondrial membrane, avoiding ATP synthesis and instead dissipating the excess of energy as heat (Figure 1) (2,5,28-31). The thermogenic potency of this mechanism is considerable, and fully activated BAT in humans has been appraised to contribute to $5 \%$ of the basal metabolic rate (32). By scaling up energetic values obtained in rodents, this effect is theoretically estimated to have the potential to increase daily energy expenditure by up to $20 \%$ (33).

BAT function is controlled by both the central and the peripheral nervous system. The sympathetic nervous system (SNS) is essential to activate BAT thermogenesis. An increase in the firing rate of the sympathetic nerves subserving BAT leads to norepinephrine release at the nerve terminal and activation of the $\beta$-adrenergic receptors ( $\beta$-ARs, which are $G$ protein coupled receptors) expressed in the brown adipocytes, mainly the $\beta_{3}$ subtype ( $\beta 3-\mathrm{AR})$. Upon receptor stimulation, associated protein Gs activates adenylate cyclase (AC), increasing cAMP, which in turn activates protein kinase A (PKA), inducing thermogenesis and downstream activation of p38 mitogen-activated protein kinase (MAPK) (2,34). PKA has both acute and chronic effects on BAT. The acute response of PKA increases lipolysis leading to elevated cytosolic free fatty acid (FFA) level. This process occurs by activation of adipose triglyceride lipase (ATGL), hormonesensitive lipase (HSL; the activated form being pHSL), and monoacylglycerol lipase (MGL), the three of them sequentially hydrolyzing triglycerides to release FFAs. Carnitine palmitoyltransferase 1a (CPT1a) introduces FFA-CoA into the mitochondria, where FA oxidation leads to the formation of NADH and FADH, which are then further oxidized in the electron transport chain (Figure 1) (2,5,35-38). Purine nucleotides such as GDP and ADPN are bonded to UCP1 in resting conditions, inhibiting it; however, FFAs, which directly activate UCP1, displace the inhibitory nucleotides, increasing UCP1 activity within seconds (2). In addition to acute effects, prolonged stimulation of BAT for hours and days will result in increased amounts of UCP1 protein, mitochondrial biogenesis, and both hyperplasia and hypertrophy of BAT $(1,2,5,39)$. Thus, although the total energy balance depends on many factors (food intake, energy expenditure, BAT thermogenesis, etc.), stimulation of BAT can have an impact on long-term energy balance and hence body weight. BAT not only increases energy expenditure, but also leads to plasma triglyceride clearance $(40)$ and improved glucose homeostasis $(41,42)$ through its ability in uptake and disposal of large quantities of lipid and glucose from the circulation for use as substrates for thermogenesis $(2,40,43)$. On this basis, brown fat has emerged as a target to combat obesity and related metabolic disorders $(6,8,33)$. This concept is of relevance because it is known that increased BAT function is a physiological counter-regulatory mechanism in high-fat diet (HFD)-induced obesity, eliciting recruitment of BAT, including increased UCP1 expression levels (44). However, using BAT as a

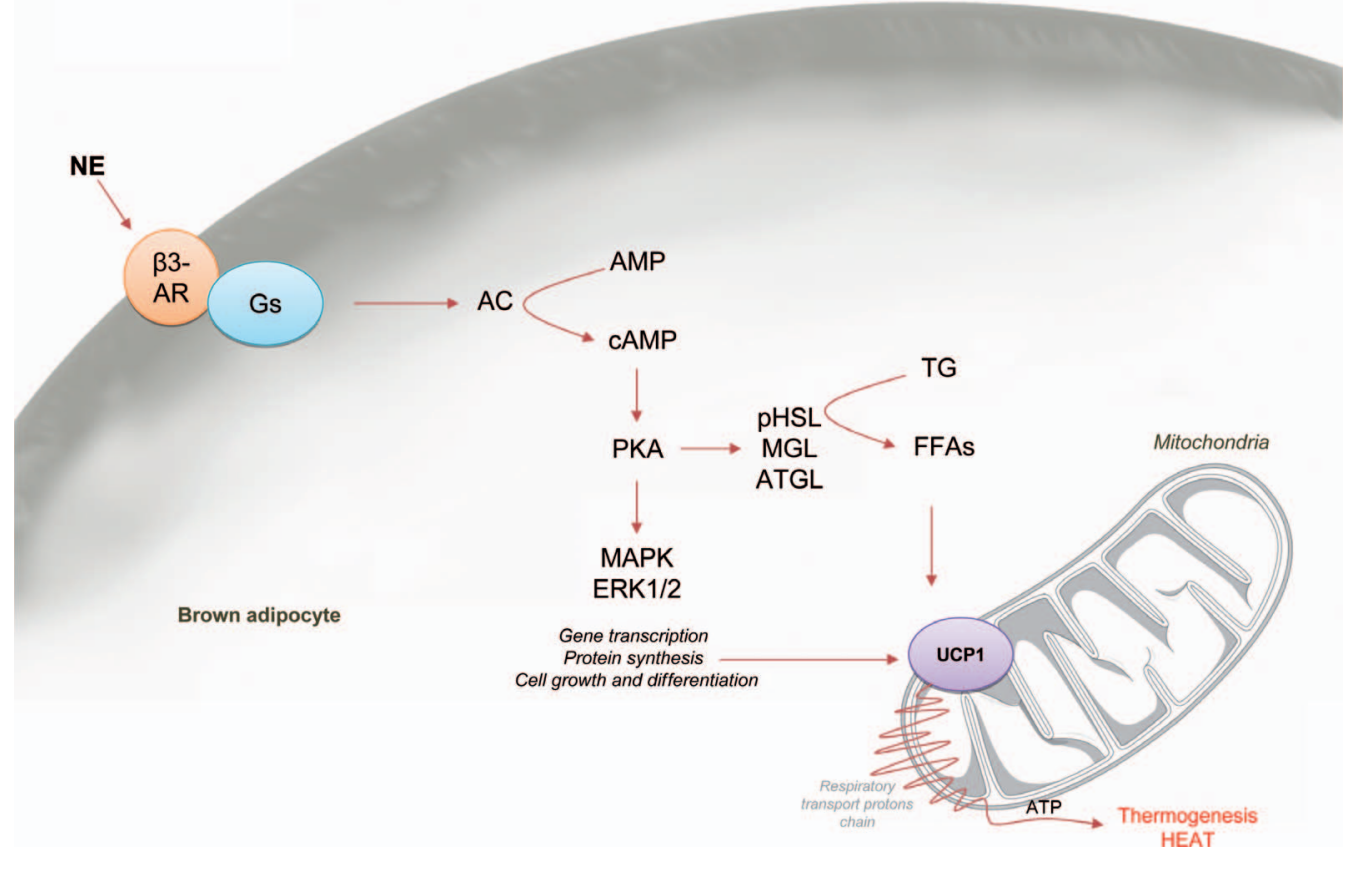

Figure 1. Brown adipose tissue uncoupling and thermogenesis. In brown adipose tissue (BAT), sympathetic stimulation releases norepinephrine (NE) activating $\beta_{3}$-adrenoreceptors ( $\beta 3$-AR) in brown adipocytes coupled to G-proteins, which activates adenylate cyclase (AC), turning AMP into cAMP that in turn activates protein kinase A (PKA). PKA induces lipolysis activating adipose triglyceride lipase (ATGL), hormone-sensitive lipase (HSL; the active isoform being pHSL), and monoacylglycerol lipase (MGL) which hydrolyzes triglycerides, diacylglycerol, and monoacylglycerol, respectively, releasing free fatty acids (FFAs). FFAs are then imported into the mitochondria through carnitine palmitoyltransferase 1a (CPT1a), where they are oxidized (via $\beta$ oxidation and further citric acid cycle), leading to the formation of $\mathrm{NADH}$ and $\mathrm{FADH}$, which are then oxidized by the electron transport chain. This results in pumping protons out of the mitochondrial matrix and the creation of a proton-motive force that drives the protons back into the mitochondrial matrix through uncoupling protein 1 (UCP1). The energy stored in the proton-motive force is then released, starting mitochondrial heat production. Furthermore, PKA activation increases UCP1 expression via mitogen-activated protein kinase (MAPK) and extracellular signal-regulated kinases (ERK)1/2 pathway responsible for gene transcription, cell growth, cell differentiation and protein synthesis. 
target organ for drugs should be approached with care, since recent evidence has demonstrated that increased BAT activity may have harmful side effects. A recent report has demonstrated that atherosclerotic plaque growth was accelerated by cold-induced BAT thermogenesis, indirectly caused by the associated increase in lipolysis. Of note, UCP1 knockout mice were protected from that effect, suggesting that activation of UCP1 function may account for low-temperature-associated cardiovascular risks (45).

\section{Novel findings about BAT in adult humans}

For a long time, BAT was considered as a tissue relevant only to rodents, hibernating mammals, and newborn humans $(1-3,5)$. However, current evidence demonstrates that BAT is also present in adult humans. Using different approaches, including positron emission tomography (PET) studies alongside ${ }^{18}$ fluorodeoxyglucose $\left({ }^{18} \mathrm{FDG}\right)$ uptake, BAT is found in defined, but dispersed, areas in the body of adult humans, distributed mainly in the cervical, supraclavicular, perirenal, intercostal, and periaortic regions $(3,12,46-48)$. Despite the initial enthusiasm following the identification of BAT in adult humans, two recent publications have reported some unexpected results regarding BAT in people. Indeed, human adipose tissue biopsies from the supraclavicular area have unexpectedly found that the expression profile of some biomarkers was closer to that of beige/brite cells than of that brown cells $(18,19)$, suggesting that human BAT may be composed of mainly beige/brite adipocytes. The process in which precursor cells placed in WAT become beige/brite cells instead of white adipocytes is called 'browning', and will be explained in the next section.

\section{Beige/brite adipose tissue: a new thermogenic organ?}

As mentioned above, there is evidence that beige/brite adipocytes exist in rodents and humans (17-22,49). According to that concept, browning consists of beige/brite adipocytes emerging in white fat depots by cold stimulation. These new cells come from a completely different lineage than the myogenic (Myf5+) lineage, as classical brown adipocytes do (15), but they still exhibit the same properties as BAT with respect to UCP1-mediated thermogenesis in response to cold. In fact, specific molecular markers of beige fat cells, rather than those of the classical brown fat cells, are enriched in the human UCP1-positive tissues, being brown-like adipocytes located in WAT depots but exhibiting the properties of classic brown adipocytes upon cold stimulation $(19,22)$. Recent data demonstrate that both cold exposure and $\beta_{3}$-adrenoreceptor agonists induce the production of beige/brite cells (20,23,50-52). Based on the above findings, activation of thermogenesis through stimulation of beige/brite adipocytes in WAT might be a new way to increase energy expenditure. Thus, these beige/brite adipocytes represent a new cell type with therapeutic potential against obesity and related metabolic disease $(6,8,53)$.

\section{Molecular determinants of browning}

\section{PPAR $\gamma$, PGC1 $\alpha$, PRDM16, and RIP140}

The first indispensable factor for browning is peroxisome proliferator-activated receptor $\gamma(\operatorname{PPAR} \gamma)$, an essential transcription factor for differentiation and survival of both brown and white adipocytes (22,54-57). PPAR $\gamma$ activation also promotes the formation of brown adipocyte-like cells, inducing the expression of UCP1, proliferator-activated receptor-gamma coactivator 1 alpha $(\mathrm{PGC} 1 \alpha)$, and other genes related to mitochondrial biogenesis, as well as those implicated in the repression of WAT genes (57). Recently, it has been demonstrated that PPAR $\gamma$ induction of brown fat genes in subcutaneous WAT is mediated by activation of PRDM16 (PR domain containing 16) (57), a process that is mediated by deacetylation of PPAR $\gamma$ by sirtuin 1 (SIRT1) (58). PRDM16 is the second determinant factor to promote brown adipogenesis in WAT $(15,59,60)$. The adipogenic actions of PPAR $\gamma$ are not restricted to BAT. It is well known that PPAR $\gamma$ is critically required for white adipogenesis, PPAR $\gamma 2$ (instead of PPAR $\gamma 1$ ) being the more potent adipogenic isoform in vivo (61-65). The specific mechanism by which PPAR $\gamma$ activation drives brown or white adipocytes depends on specific transcription factors. In fact, mesenchymal stem cells give rise to precursor cells of bone, muscle, and fat under appropriate conditions. PPAR $\gamma+\mathrm{CD} 24+$ white adipocyte precursor cells reside in mural cell compartments of the adipose vasculature. White adipocyte differentiation is driven by the transcription factors PPAR $\gamma$ and C/EBPs (CCAAT-enhancer-binding proteins), specially $\mathrm{C} / \mathrm{EBP} \alpha$, giving rise to triglyceride-storing WAT. This proliferating WAT precursor cell population constantly reconstitutes WAT depots throughout adult life and can react to increased demand for energy storage with increased differentiation. Brown fat cells share precursors (Myf5+) with muscle cells but not with white adipocytes. Induction of PRDM16 expression in Myf5 + cells directs them to develop into brown fat cells $(15,66)$. In the absence of PRDM16, these precursor cells will develop into muscle cells under the influence of the transcription factors myogenin and MyoD (myogenic differentiation protein) $(15,66,67)$.

PGC1 $\alpha$ is increased by cold exposure (68), and controls mitochondrial biogenesis and nuclear respiratory factors, making it indispensable for proper thermogenesis but not for BAT differentiation $(56,68,69)$. PRDM16, similarly to PPAR $\gamma$, is involved in the regulation of both BAT and WAT genes (70-72). PRDM16 is able to interact with $\mathrm{PGC1}$ and $\mathrm{CtBPs}$ (C-terminal-binding proteins) to activate brown fat genes and suppress white fat genes, respectively (73). Genetic overexpression of PRDM16 increases energy expenditure and improves glucose tolerance in HFD mice through augmented brown-like adipocytes in WAT, while depletion of PRDM16 in vitro has been shown to decrease UCP1 expression (74). Stimulation of BAT-specific genes by PRDM16 requires association with PGC1 $\alpha$ and PGC1 $\beta$ (66), which are the third activators of browning as well as coactivators of PPAR $\gamma(18,57)$.

RIP140 (receptor-interacting protein 140) is a nuclear receptor co-regulator highly expressed in metabolic and reproductive tissues (75). Its overexpression inhibits genes involved in mitochondrial biogenesis and oxidative metabolism (76-78). By contrast, deletion of RIP140 increases brown-like adipocytes in WAT (76). RIP140-null mice have a 70\% reduction in total body fat mass and have higher oxygen consumption when fed a HFD; these mice are resistant to obesity and have elevated expression of UCP1 in WAT $(76,79)$. In brown adipocytes, RIP140 suppresses UCP1 by antagonizing the binding of PPAR $\gamma / \mathrm{PGC} 1 \alpha$ to the UCP1 promoter $(80,81)$. Consistently, its overexpression inhibits genes involved in mitochondrial biogenesis and oxidative metabolism (76-78).

\section{Irisin: role of exercise}

In 2012, Boström and colleagues identified irisin, a muscle tissuesecreted peptide, proposing a possible mechanism by which exercise increases BAT activity (82). During exercise, PGC1 $\alpha$ is induced in the muscle of rodents and humans $(83,84)$. As a consequence, fibronectin type III domain containing (FNDC5) is released and further cleaved to irisin. This active form of the protein can act on different tissues, among them BAT, where it increases 
its thermogenic activity by increasing UCP1 expression $(82,85)$. Irisin also stimulates browning by increasing the expression of UCP1 and other BAT-genes in subcutaneous WAT through mitogen-activated protein kinase p38 MAP kinase and ERK MAP kinase signaling (85), while genes characteristic of WAT are downregulated (84). More recently, one report showed that the actions of irisin might be of clinical value since both irisin and fibroblast growth factor (FGF21; see below) are cold-induced endocrine activators of BAT activity in humans (86). However, there are also several studies that have shown controversial results, and some authors failed to document an effect by contraction in circulating irisin levels in humans or an effect on beige/brite differentiation of human preadipocytes $(87,88)$. Therefore, the potential beneficial metabolic actions of irisin during exercise are still under debate, and some issues await clarification. These include the full characterization of the different tissues expressing irisin (89) and, more importantly, the different proteolytic mechanisms involved in its post-translational processing and the generation of putative secreted molecules (90). Thus, it seems obvious that further studies are needed to elucidate, in depth, this field.

\section{Transient receptor potential V4 channel}

The transient receptor potential (TRP) family of cation channels mediates sensation across a broad physiological range of temperatures. Several TRP members have been described, each of them sensing a particular temperature range. The TRPM8 channel is activated by modest cooling (environmental temperatures $\left.<27^{\circ} \mathrm{C}\right)(91,92)$, and TRPM8-deficient mice exhibit a reduced ability to tolerate innocuous cold temperatures (93-95). TRPA1 is activated by colder temperatures (environmental temperatures $<17^{\circ} \mathrm{C}$ ) than TRPM8 (96-98), while TRPV1 is activated by a noxious range of heat $\left(>43^{\circ} \mathrm{C}\right)(99,100)$. TRPV 3 and TRPV4 are warm-sensitive channels activated by innocuous warm temperatures, with environmental temperature thresholds of $33-39^{\circ} \mathrm{C}$ and $25-34^{\circ} \mathrm{C}$, respectively (101-105). TRPV4 was first identified as an osmolality sensor $(10,106,107)$, and it is highly expressed in adipose tissue (106), where it acts as a negative regulator of PGC1 $\alpha$, UCP1, and cellular respiration and therefore as an inhibitor of the thermogenic program in WAT (108). Additionally, it potently controls the expression of multiple proinflammatory genes involved in the development of insulin resistance (108). This evidence is also supported by functional data of genetic ablation or pharmacological inhibition of TRPV4, both of which modulate thermogenic and proinflammatory pathways in adipose tissue (108). Furthermore, genetic ablation of TRPV4 induces elevated thermogenesis and protects from diet-induced obesity, adipose inflammation, and from insulin resistance $(10,108)$, suggesting that inhibition of TRPV 4 could be a target for treating obesity and type 2 diabetes by inducing a thermogenic program in white adipocytes. Whatever the case, due to its alleged role in regulating osmotic pressure in the kidney, some possible secondary effects should be considered when regarding TRPV4 as a drug target $(109,110)$.

\section{Natriuretic peptides}

The cardiac natriuretic peptides (NPs), atrial NP (ANP) and ventricular NP (BNP), are potent vasodilators secreted by heart muscle cells in response to high blood volume. A thermogenic effect of NPs, in both mice and human adipocytes, was recently demonstrated (111). Thus, when NPs bind to their receptors (NPR) on brown adipocytes, this activates p38 MAPK for induction of the expression of Ucp 1, Pgcla, and other genes implicated in thermogenesis. Chronic administration of BNP also increases browning in white fat and enhanced oxygen consumption and energy expenditure. Accordingly, in mice exposed to cold, in which BAT activity is increased, plasma levels of NPs were elevated (111). The physiological significance of these data is intriguing $(9,10)$, but it would be reasonable to think that BAT thermogenesis would demand higher cardiac activity, and NPs would establish a logic communication between heart and BAT. Further studies are required for a better understanding of this heart-BAT axis.

\section{Retinoids}

Retinoids, such as vitamin A (retinol), are involved in multiple essential biological functions including fuel metabolism by controlling adipogenesis and energy homeostasis (112-114). Retinoic acid (a metabolite of retinol) is a direct activator of sympathetic activity and an inducer of UCP1 expression in BAT and WAT. In fact, its chronic administration induces browning in white adipocytes $(9,10,115,116)$.

\section{Prostaglandins}

Prostaglandins (PG) are a group of lipid compounds involved mainly in inflammation, fever induction, and pain. Cyclooxygenase-2 (COX-2) is a key enzyme in PG formation. COX-2 has been described as downstream effector of $\beta$-adrenergic signaling in WAT, being required for the induction of brown adipocytes in WAT depots, increasing energy expenditure, and protecting against HFD-induced obesity $(10,117)$. Genetic and pharmacological approaches have shown that COX-2 and prostaglandin $\mathrm{E}_{2}\left(\mathrm{PGE}_{2}\right)$ are involved in UCP1 expression in white, but not in brown adipocytes, suggesting that the browning process in WAT is COX-dependent (118). Current evidence has also demonstrated that lipocalin prostaglandin D synthase (L-PGDS) plays also a role in fuel utilization by BAT (119). In fact, under cold-acclimated conditions, mice lacking L-PGDS show elevated reliance on carbohydrate to provide fuel for thermogenesis and increased expression of genes regulating glycolysis and de novo lipogenesis in BAT. These transcriptional differences are associated with increased lipid content in BAT and a BAT lipid composition enriched with de novo synthesized lipids. Actually, given that L-PGDS knockout mice showed unchanged levels of PGD2 in BAT, this suggests that L-PGDS may act as a lipocalin (lipid binding protein) rather than as a prostaglandin synthase. Moreover, L-PGDS knockout mice exhibit increased expression of genes involved in thermogenesis and increased norepinephrinestimulated glucose uptake to BAT (119).

\section{Peripheral regulation of BAT}

\section{Thyroid hormones}

Thyroid hormones (THs) are produced in the thyroid gland in the form of thyroxine (T4) which is an inactive prohormone with low biological activity. T4 is transformed into the bioactive hormone triiodothyronine (T3) by catalytic action of enzymes iodothyronine deodinases (D1 and D2) expressed in different tissues (120-124). THs play a key role in energy metabolism acting on peripheral tissues, such as liver, pancreas, skeletal muscle, WAT, and BAT (124). Thereby, animal models and patients with hyperthyroidism, characterized by high circulating levels of $\mathrm{TH}$, show weight loss despite increased food intake, due to very high caloric demand (124-130). By contrast, hypothyroidism is associated with decreased metabolic rate, with increased body weight despite reduced food intake (124-126,131-134).

BAT is a direct target of THs and displays high expression of $\mathrm{TH}$ receptors (TR). In fact, THs work synergistic with norepinephrine and are required to generate a full thermogenic response $(124,130,135)$. The TR $\alpha_{1}$ subtype in BAT ensures maintenance of normal adrenergic thermogenic response, while the $\operatorname{TR} \beta_{1}$ sub- 
type increases Ucp1 gene expression $(136,137)$. The functional relevance of THs on BAT is supported by animal data (138-142). Genetic and pharmacological approaches have confirmed the role of the different TR isoforms in BAT thermogenesis, showing that TR deficiency leads to hypothermia and cold intolerance associated with reduced BAT thermogenesis due to sympathetically impaired response, although morphology, recruitment, and development of BAT are unaltered (138-142). Furthermore, D2 is well recognized as an important enzyme in BAT physiology for $\mathrm{TH}$-induced thermogenesis (143-146), and studies on genetic models with ablation of D2 expression suggest that D2-catalyzed T4 to T3 conversion is required to support BAT adrenergic responsiveness to generate heat in response to cold exposure (147-149). This evidence has been partially confirmed in humans, where chronic exposure with $\mathrm{TH}$ increased both brown adipose tissue activity and volume, as well as the expression of TH-responsive genes, such as Ucp1, leading to improvement in glucose control (150).

\section{Leptin}

The importance of leptin in the regulation of thermogenesis is well established. Leptin is a circulating hormone/cytokine which is released mainly by subcutaneous white adipose tissue, and has effects in both the central nervous system (CNS) and in peripheral tissues (151-155). Centrally, leptin controls food intake, energy expenditure, fat distribution, insulin sensitivity, FFAs oxidation, and lipolysis in the periphery. It is known that leptin increases SNS activity to BAT (156), and that $o b / o b$ (leptin-deficient) mice, $d b / d b$ (leptin receptor-deficient) mice, and $f a / f a$ (leptin receptor-deficient) rats have atrophied BAT, with little UCP1 expression, leading to reduced BAT activity and impaired thermogenesis $(157,158)$. The thermogenic effect of leptin is mediated by the melanocortin system, more specifically through stimulation of $\alpha$-melanocyte-stimulating hormone $(\alpha-\mathrm{MSH})$ release, which then activates sympathetic outflow to BAT. Thus, leptin binding to its receptor, LEPR-B, leads to an increase of proopiomelanocortin (POMC) and a decrease of neuropeptide Y (NPY)/agouti-related protein (AgRP) levels. The overall consequence is triggering of SNS activation, which leads to an increase of UCP1 transcription and thermogenesis in BAT (159).

\section{Insulin}

Insulin is secreted in pancreatic $\beta$-cells in response to circulating glucose increase, acting as an anabolic hormone in peripheral tissues. BAT is one of the most insulin-responsive tissues with respect to stimulation of glucose uptake $(2,160)$. Physiological conditions in which plasma insulin levels are elevated (refeeding) show increased glucose uptake into BAT $(2,161,162)$, whereas states with low insulin levels (starvation or fasting) demonstrate reduced glucose uptake $(2,162,163)$. In rodents, it was also found that insulin can promote thermogenesis through its action in the brain, triggering sympathetic activation to BAT (164). Interestingly, insulin infusion increased glucose-uptake in BAT to levels similar to that in skeletal muscle, which could be associated to the high expression of GLUT4 in BAT, although it was not accompanied by concomitant thermogenesis unlike cold exposure (165). Phosphatidylinositol-3-kinase (PI3K), a major kinase mediator of insulin and insulin-like-growth factors, is counteracted by phosphatase and tensin homolog (PTEN). Recent data showed that PTEN positively regulates a BAT-selective thermogenic program by blocking the PI3K pathway (166). Importantly, pharmacological PI3K inhibitors increase BAT thermogenesis and whole-body energy expenditure (166). However, the systemic significance of brown adipocytes for insulin-induced glucose clearance was demonstrated using transgenic mice lack- ing the insulin receptor in BAT (BATIRKO) in which the weight of BAT is decreased and enzymes of fatty acid synthesis are decreased (without change in the number of brown adipocytes), suggesting that insulin action is necessary for lipid accretion in BAT (41). In parallel, these mice develop an insulin-secretion defect, providing evidence that BAT plays a role in the regulation of insulin secretion (41).

\section{Adiponectin}

Adiponectin (ADPN; also called adipocyte complement-related protein (Acrp30), apM1, or adipoQ) is a 244-amino-acid protein secreted from adipose tissue (167-170), placenta (171), and cardiomyocytes (172), among other tissues. ADPN increases fatty acid combustion and energy consumption via PPAR $\alpha$ activation, leading to decreased triglyceride content mainly in the liver and skeletal muscle through activation of AMP-activated protein kinase (AMPK; see below) activity (173). Adiponectin also increases hypothalamic AMPK activity via its receptor AdipoR1 to stimulate feeding (174-176). Recent evidence has shown that ADP reduces thermogenesis by inhibiting BAT function. ADPN treatment reduces PKA signaling (177) and UCP1 expression in BAT $(45,174,178)$. In keeping with this, genetic ablation of the Adpn gene increases body temperature, increases Ucp 1 expression in BAT, and more brown-like structure in inguinal fat compared to wild-type mice (179). Reconstitution of ADPN in these animal models blunted $\beta$-adrenergic receptor agonist-induced thermogenesis of interscapular BAT (179). Taken together, these data suggest that the suppressive effect of ADPN on BAT thermogenesis could be associated to an increase in hypothalamic AMPK activity (see below), an idea that needs to be confirmed.

\section{Resistin}

Resistin (RSTN) is an adipokine, originally identified in adipose tissue (180) but expressed in a variety of tissues, including the hypothalamus (181). Recently it has been demonstrated that resistin activates the ERK1/2 signaling pathway in the hypothalamus, involved in diverse cellular functions including cell growth, proliferation, and neuronal activity, which, in turn, reduces BAT thermogenesis $(182,183)$. This evidence, alongside RSTN's anorectic role and its effect on hypothalamic AMPK $(184,185)$, points towards an extensive role of this adipokine in the modulation of BAT function.

\section{Adrenal steroids}

Glucocorticoids (such as cortisol and corticosterone) and mineralocorticoids (aldosterone) are steroid hormones secreted in the adrenal cortex and involved in metabolism, cell growth, and regulating ion and water transport. Cortisol acts by binding to the glucocorticoid receptor (GR), while aldosterone acts through the mineralocorticoid receptor (MR). The presence of GR on brown adipocytes was described many years ago (186): its activation in BAT reduces UCP1 expression $(187,188)$. MR is also expressed in brown fat (189). Subsequently, studies in cells show that aldosterone inhibited the expression and function of UCP1 in brown adipocytes (187), while aldosterone treatment induced a significant increase of triglyceride's accumulation in WAT and increased expression of adipogenic genes (lipoprotein lipase-Lpl-, Ppar $)$ (190). These data suggest that GR and MR signaling in BAT appears to act as a pivotal signal favoring lipid storage at the expense of heat production, hence promoting in brown adipocytes a specific function of white adipocytes.

\section{Fibroblast growth factor}

FGF21 is a metabolic regulator involved in the control of glucose homeostasis, insulin sensitivity, and ketogenesis, mainly 
produced in the liver from where it is released into the blood (191-194). There is evidence that FGF21 is also involved in BAT-induced thermogenesis (195). Current data have provided a mechanistic explanation, showing that induction of cAMP in brown adipocytes induces FGF21 release from BAT in response to noradrenergic stimulation (196). FGF21 expression is under the control of PPAR $\alpha$ and FFAs availability, and has also been reported to promote thermogenic activity, increasing energy expenditure, and UCP1 expression in vivo as well as in vitro in WAT (197). In fact, mice deficient in FGF21 display an impaired ability to adapt to chronic cold exposure, with diminished browning of WAT (197). Adipose-derived FGF21 increases the expression of UCP1 and other thermogenic genes in fat tissues, regulating this process, at least in part, by enhancing adipose tissue PGC1 $\alpha$ protein levels and also cyclic adenosine $5^{\prime}$-monophosphate response element-binding protein (CREB) and downstream genes associated with oxidative metabolism $(195,198,199)$.

Recent findings have shown that FGF21 also exerts central actions on energy homeostasis. In HFD-fed rats, FGF21 intracerebroventricular (ICV) injection increases feeding, elevates energy expenditure, and improves insulin sensitivity, although with no changes in body weight (200). On the other hand, genetic models of $\beta$-Klotho (transmembrane protein that acts with FGF receptors) ablation in the suprachiasmatic nucleus of the hypothalamus (SCN) and the dorsal vagal complex (DVC) simulate features of physiological starvation response, such as increased glucocorticoid levels, suppressed physical activity, and altered circadian behavior (201). Overall, this evidence has led to the proposal of FGF21 as a novel appealing therapeutic reagent for type 2 diabetes mellitus and obesity. However, its clinical development has been challenging due to its poor pharmacokinetics (202).

\section{Central regulation of thermogenesis: the anatomical issue}

Normothermia in a cold environment is maintained in part through metabolic activation of BAT in order to generate heat, besides skin vasoconstriction to avoid heat loss. Both processes are regulated by SNS and accompanied by adrenergic cardiac stimulation, to improve distribution of heat generated in thermogenic tissues (203-206). Furthermore, somatic motor nerves promote the generation of heat by skeletal muscle through shivering (207). In addition to these changes, cold responses engage activation of the thyroid and adrenal axes $(208,209)$. All of these changes are co-ordinated at the central level, and in this section we will describe the main central circuits regulating BAT thermogenesis (5), summarized in Figures 2 and 3.

\section{The preoptic area: the temperature central sensor}

For many years the preoptic area (POA), also called anterior hypothalamic nucleus, has been considered the only region in the brain responsible for the control of thermoregulation, where cold-sensitive neurons are located (210-214). The POA also receives input from thermosensitive areas elsewhere in the body. Cold and heat receptors in the abdominal viscera send temperature information through splanchnic and vagus nerves to the CNS, where it is integrated into the final response $(211,215)$. Temperature changes could also be sensed by the spinal cord, which contains thermoreceptors detecting cold environment (216). It is well known that electric stimulation of POA activates BAT $(217,218)$. The POA also contains heat-sensitive neurons whose tonic discharge is reduced by skin cooling and whose thermosensitivity to preoptic temperature is increased when the skin is cooled (219). As a result, skin cooling or direct cooling of POA neurons induces sympathetic thermogenesis in BAT, as well as shivering thermogenesis $(212,220)$. Within the POA cold appears to signal mainly to the median part ( $\mathrm{MnPO}$ ), where glutamatergic stimulation with $\mathrm{N}$-mehyl-D-aspartate (NMDA) induces physiological responses mimicking a cold-defensive response (221). On the contrary, stimulation of the medial POA (MPO) or lateral POA (LPO) does not recapitulate that effect (221). Furthermore, the POA projects to other central nuclei, modulating thermogenesis. Indeed, destruction of the ventromedial nucleus of the hypothalamus (VMH; see below) abolishes the ability of external cooling signaling to POA to stimulate BAT $(222,223)$, suggesting that POA activation of BAT is meditated by the VMH.

Febrile responses are also mediated by the POA. Fever is a physiological condition that requires an increase of body temperature in response to endogenous pyrogens released, for example, during infection. This provides an optimal hyperthermic environment for mounting host defenses against invading bacteria or viruses, while reducing pathogen viability (213). Prostaglandins $(\mathrm{PG})$, which are involved in mediating the febrile response, are synthesized in the brain vasculature and in peripheral tissues in response to immune signals. Besides previously mentioned effects on BAT thermogenesis and browning, there are studies using lipocalin prostaglandin D synthase (L-PGDS; which synthesizes $\mathrm{D}$-series $\mathrm{PG}$ ) demonstrating that L-PGDS $\mathrm{mRNA}$ in BAT is strongly and positively correlated with activation of BAT metabolism $(119,224)$. Prostaglandins $\mathrm{E}_{2}\left(\mathrm{PGE}_{2}\right)$ also stimulate POA, activating BAT thermogenesis in a cAMP-dependent manner $(225,226)$. In addition, the inhibitor of phosphodiesterase (the enzyme degrading cAMP), blunts fever induced by intra-POA PGE (227). Thereby POA is known as a 'fever or thermoregulatory center'. The POA population with EP3 subtype of PGE receptor (EP3) is mainly GABAergic and projects to neurons at the dorsomedial nucleus of the hypothalamus $(\mathrm{DMH})$ and the rostral raphe pallidus nucleus $(\mathrm{rRPa})$, antagonizing $\mathrm{GABA}_{\mathrm{A}}$ receptors and inducing fever by activating BAT thermogenesis (228). Fibers connecting POA to the DMH and rRPa will be explained below.

\section{The ventromedial nucleus of the hypothalamus: the integrator center of peripheral signals}

The VMH was the first identified as a hypothalamic site involved in thermoregulation. It was reported that electrical stimulation of that nucleus increased interscapular BAT temperature, and that this effect was abolished by $\beta$-adrenergic blockade (217,229-233). Also, GABA agonists applied into the VMH abolish the prostaglandin $\mathrm{E}_{2}$-induced $\mathrm{BAT}$ activation via a sympathetic efferent mechanism $(225,234)$. On the other hand, glutamate injection into the VMH was shown to activate BAT (233-236), an effect promoted also by hydroxybutyrate (237), norepinephrine, serotonin, and tryptophan (238). Anatomical data have also demonstrated a link between the VMH and BAT. First, there is evidence that the VMH can be trans-synaptically infected from BAT with pseudorabies virus. For instance, 6 days after BAT inoculation with a transneuronal viral tract tracer, Bartha's $\mathrm{K}$ strain of the pseudorabies virus, the infection penetrates into the VMH (239), an effect considered at some point controversial (240). Second, there are projections from the VMH to autonomic centers $(2,127,241,242)$. In addition, there are several brainstem areas, such as the raphe pallidus $(\mathrm{RPa})$ and inferior olive (IO), two nuclei which have been functionally linked to the regulation of BAT thermogenesis (240,243-246), where VMH neurons have been postulated to relay to modulate SNS activity $(2,127,241)$. However, the role of the VMH in the regulation of BAT activity remains controversial due to the lack of 


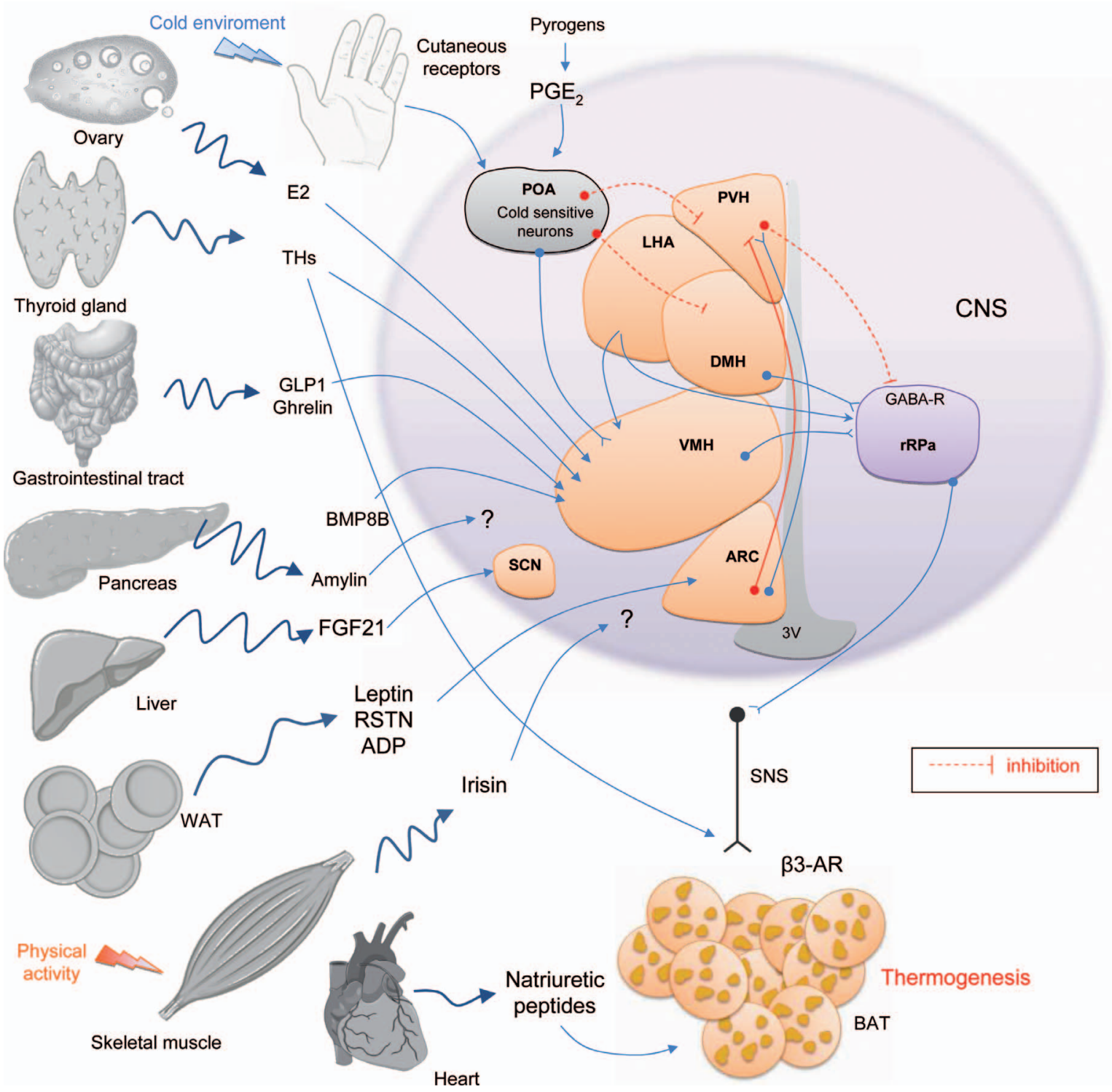

Figure 2. Regulation of brown adipose tissue thermogenesis. The preoptic area (POA) is the brain region responsible for receiving temperature signals from peripheral areas. Thus, when cold environment activates cutaneous receptors, or pyrogens induce prostaglandins, cold-sensitive neurons in the POA are activated for inducing thermogenesis: 1) through projections to the ventromedial hypothalamic nucleus (VMH) which activates sympathetic fibers to brown adipose tissue (BAT), and 2) through disinhibition of a neural population in the dorsomedial hypothalamic nucleus (DMH), which projects preganglionic fibers to the rostral raphe pallidus nucleus ( $\mathrm{rRPa}$ ), leading to activation of sympathetic projections to BAT. Thyroid hormones (THs; which are released by the thyroid gland and also directly activate thermogenesis in BAT), bone morphogenetic protein 8B (BMP8B), estradiol (E2), and glucagon-like peptide-1 (GLP-1; secreted by the intestinal tract), inhibit AMPK activity (not shown; see Figure 3) in the ventromedial hypothalamic nucleus (VMH), leading to the activation of BAT thermogenesis by sympathetic nerves. Some evidence supports that ghrelin may well be involved in activation of BAT thermogenesis; however, definitive proof is lacking. Leptin is released from white adipose tissue (WAT) acting on leptin receptors (LEPR-B) in the arcuate nucleus of the hypothalamus (ARC), leading to activation of BAT thermogenesis. The mechanisms mediating the central actions of adiponectin (ADPN) and resistin (RSTN) on BAT is not clarified. Neurons in the paraventricular hypothalamic nucleus (PVH) inhibit sympathetic signaling to BAT. Amylin, secreted by the pancreas, induces sympathetic activation of BAT thermogenesis through hypothalamic mechanisms not yet elucidated. Physical activity induces irisin release in skeletal muscle, which not only induces thermogenesis, but also activates the browning process in WAT, increasing oxygen consumption, uncoupling protein (UCP1) expression, and decreasing WAT genes (not shown in the Figure in order to simplify). In the same way, fibroblast growth factor 21 (FGF21) is secreted by the liver and also promotes browning. Natriuretic peptides, released by the heart, act directly on BAT receptors activating thermogenesis. In summary, BAT regulation is a complex and multifactorial process carried out mainly in the hypothalamus to adjust thermogenic responses, according to metabolic demands of the body. $3 \mathrm{~V}=$ third ventricle.

information about the precise neuronal pathways that connect the VMH to BAT (247).

More recently, genetic evidence has also supported the role of the VMH in the modulation of BAT thermogenesis. For example, VMH-specific knockout of steroidogenic factor-1 (SF-1) shows lower energy expenditure and expression of UCP1 in BAT $(248,249)$. On the other hand, silencing estrogen receptor $\alpha(E R \alpha)$ in the VMH increases body weight gain, visceral adiposity, hyperphagia, hyperglycemia, and reduces thermogenesis in
BAT, leading to metabolic syndrome (250). Moreover, mice bearing conditional ER $\alpha$ knockout in SF1 neurons exhibit reduced plasma levels of norepinephrine and thermogenesis in BAT, with decreased UCP1, PPAR $\gamma$, PGC1 $\alpha$, and $\beta 3$-AR expression (251). These data support the idea that the VMH is a key modulator of BAT. We have extensively studied the mechanisms within the VMH that regulate BAT activity. Our studies point towards AMPK in the VMH as a key negative regulator of sympathetically activated BAT thermogenesis, integrating peripheral signals, such 


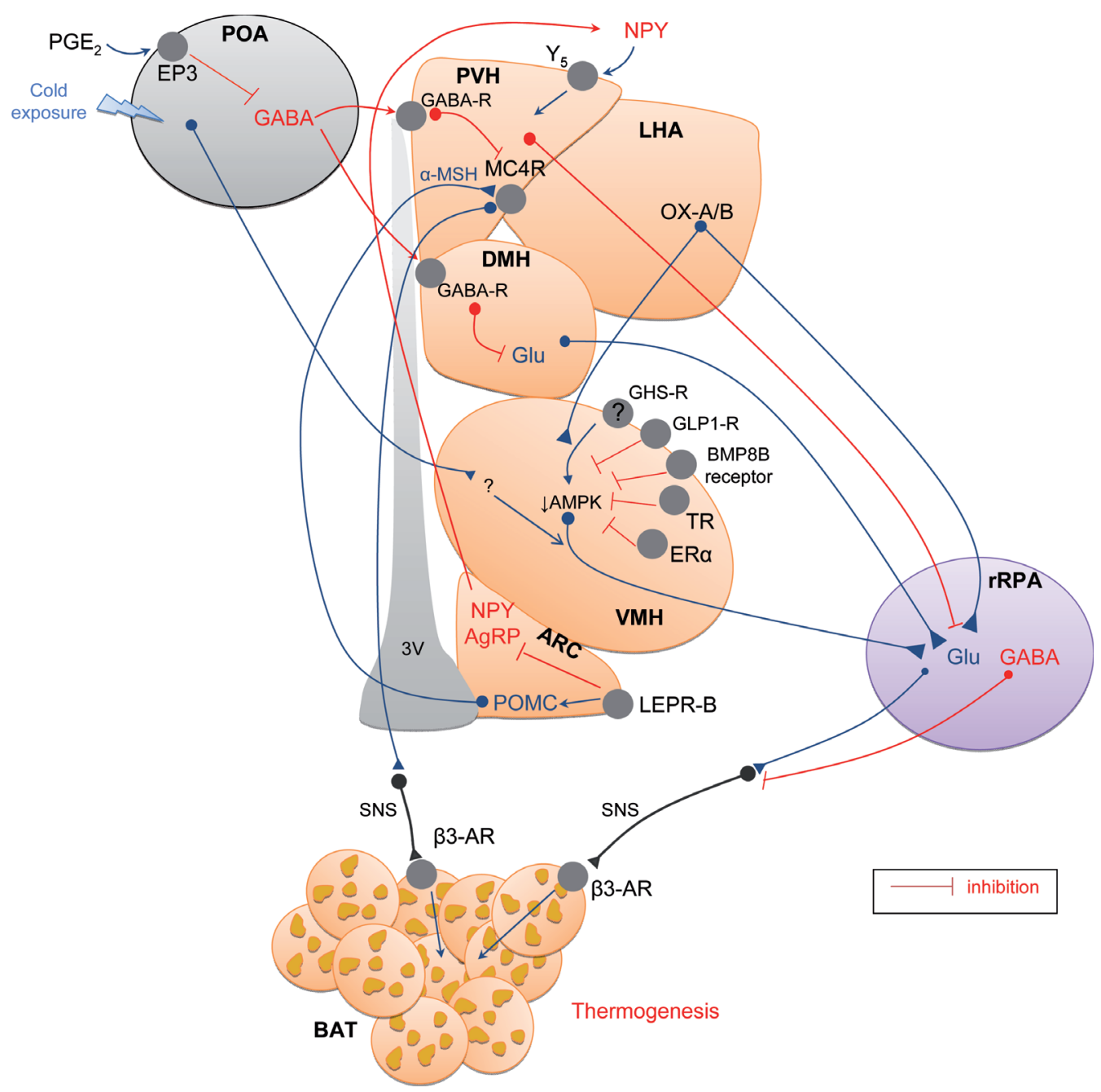

Figure 3. Interactions of hypothalamic nuclei regulating BAT thermogenesis. All complex peripheral signals are integrated at the central nervous system regulating the final output to brown adipose tissue (BAT). The main brain region to integrate them is the hypothalamus where different nuclei play key roles in the thermogenic response. Other brain sites, such as the preoptic area (POA) and rostral raphe pallidus (rRPa), also are involved in this network regulation. Therefore, cold exposure induces neuronal activation of POA, which projects to other neurons in the ventromedial nucleus of hypothalamus (VMH), leading to activation of sympathetic fibers to BAT. There are several lines of evidence showing that this mechanism involves AMP-activated protein kinase (AMPK), which can be regulated by glucagon-like-peptide 1 (GLP-1), bone morphogenetic protein 8B (BMP8B), thyroid hormones (THs), or estradiol (E2), all of which induce sympathetic activity to BAT by decreasing AMPK activity. Some evidence supports that ghrelin may well be involved in activation of BAT thermogenesis; however, definitive proof is lacking. The dorsomedial nucleus of hypothalamus (DMH) is highly involved in BAT regulation. The DMH projects fibers to the rRPa inducing BAT activity by increasing sympathetic tone. The paraventricular nucleus of hypothalamus (PVH) is also involved in the modulation of BAT thermogenesis by projecting inhibitory fibers to the rRPa. The lateral hypothalamic area (LHA) contains orexin (OX-A and OX-B)expressing neurons which project to the $\mathrm{VMH}$ and the rRPa, activating BAT thermogenesis. The arcuate nucleus of hypothalamus (ARC) is characterized by the presence of an orexigenic neural population (coexpressing neuropeptide Y (NPY) and agouti-related protein (AgRP)) and an anorexigenic neuron population (coexpressing proopiomelanocortin (POMC) and cocaine- and amphetamine-regulated transcript which are inversely regulated by leptin. Leptin induces POMC expression and releasing of $\alpha$-melanocyte-stimulating hormone $(\alpha-\mathrm{MSH})$, which binds to melanocortin-4 receptor (MC4R) within PVH, activating sympathetic fibers to BAT. Leptin also inhibits NPY and AgRP which inhibits sympathetic neurons to BAT trough PVH fibers. 3V $=$ third ventricle; $\beta 3-\mathrm{AR}=\beta 3$-adrenergic receptor; $\mathrm{ER} \alpha=$ estrogen receptor alpha; $\mathrm{GABA}-\mathrm{R}=\mathrm{GABA}$ receptor; GHS-R=growth hormone secretagogue receptor; GLP1-R = GLP-1 receptor; Glu = glutamate; LEPR-B = leptin receptor isoform B; SNS = sympathetic nervous system; $T R=$ thyroid hormone receptor; $\mathrm{PGE}_{2}=$ prostaglandin $\mathrm{E}_{2} ; \mathrm{EP} 3=$ prostaglandin $\mathrm{E}$ receptor type 3.

as thyroid hormone, estradiol, and BPM8b, as well as drugs such as nicotine $(127,241,252,253)$.

\section{The dorsomedial nucleus of the hypothalamus}

The DMH plays key roles in feeding and metabolic regulation associated with ingestive behavior $(247,254,255)$, which is closely related to thermoregulation. After many years of controversial data, there is evidence that activation of neurons in the $\mathrm{DMH}$ elicits an increase in body temperature through a classic thermoregulatory mechanism $(228,247,256)$. Excitatory aminoacid receptors in the DMH mediate prostaglandin-evoked ther- mogenesis in BAT (257). In keeping with this, disinhibition of DMH neurons increases BAT sympathetic activation and thermogenesis $(228,256)$. The cellular basis of this mechanism is not totally clear, but GABAergic neurons in the POA appear to provide a key source of the tonic inhibitory input to sympathetic nerve fibers in the DMH (228,258-261). However, neurons in the DMH do not project directly to BAT sympathetic fibers, but they rather send monosynaptic projections to the rRPa that have been involved in mediating the effects of DMH neurons on BAT thermogenesis. Thus, disinhibition of neurons in the DMH activates glutamate receptors in the $\mathrm{rRPa}$, triggering $\mathrm{BAT}$ sympathetic 
activation and thermogenesis (262). Functional data support this concept; in fact, inhibition of neurons in the $\mathrm{DMH}$ or blockade of local glutamate receptors in the $\mathrm{DMH}$ reverses febrile and cold-evoked excitations of SNS and subsequent stimulations of BAT thermogenesis $(256,262,263)$. Other data suggest that the IO may also have a role in the SNS control of BAT and that this nucleus may also be involved in functional interactions between the motor and thermoregulatory systems, through the DMH in the same way as the $\mathrm{rRPa}(5,245)$. Overall, the reported evidence so far suggests that, in a normothermic environment, GABAergic neurons in the POA tonically inhibit the DMH. However, in a cold environment, signals from somatosensory nerves in the skin activate GABAergic neurons suppressing the tonic firing of the GABAergic neurons in the POA, leading to disinhibition of DMH neurons, which in turn stimulate neurons in the rRPa controlling BAT sympathetic tone and the IO, and therefore stimulating thermogenesis.

Recent findings raise the possibility of alternative mechanisms through which the DMH activates BAT thermogenesis. This is based on the finding that there are leptin receptors on the $\mathrm{DMH}$ which are involved in the stimulation of the $\mathrm{rRPa}$ and consequent sympathetic activation of BAT $(264,265)$. Finally, there is evidence suggesting that knockdown of NPY specifically in the DMH promotes both the development of brown adipocytes in WAT and also BAT activity, increasing thermogenesis and energy expenditure (266). Furthermore, this manipulation prevents HFD-induced obesity and improves glucose homeostasis (266). Leptin is probably involved in this process by activating NPY in the DMH (267), although more studies are needed to elucidate this mechanism. Finally, the hypothalamic factor modulating the hypothalamic-pituitary-adrenal (HPA) axis, namely, corticotrophin-releasing hormone (CRH), increases BAT thermogenesis through the $\mathrm{DMH}$ and $\mathrm{mRPa}$ (268).

\section{The paraventricular nucleus of the hypothalamus}

The paraventricular nucleus of the hypothalamus (PVH) plays an important role in energy homeostasis; however, its possible involvement in the regulation of thermogenesis and energy expenditure in BAT has been controversial. Because PVH neurons that project to the spinal sympathetic preganglionic cell column are activated during fever (269), and lesions of the PVH attenuate fever (270-272), it was initially thought that neurons in the $\mathrm{PVH}$ played a role in the excitation on BAT thermogenesis. This evidence was also supported by anatomical data demonstrating that the PVH is heavily trans-synaptically infected from BAT with pseudorabies virus $(239,273,274)$ or the H129 strain of the herpes simplex virus-1 (HSV-1) (275). However, electrical stimulation of the PVH does not affect BAT $(276,277)$. Furthermore, disinhibition of neurons in the $\mathrm{PVH}$, or their glutamatergic activation with NMDA, inhibits the increases in BAT sympathetic nerve activity evoked by cooling $(277,278)$. Besides this, activation of PVH neurons could attenuate the increases in BAT activity evoked by NMDA injections into the rRPa (277), suggesting the existence of inhibitory projections from the $\mathrm{PVH}$ to $\mathrm{rRPa}$ decreasing sympathetic nerve activity to BAT. On the other hand, there are studies demonstrating that NPY inhibits BAT through $\mathrm{Y}_{5}$ receptors in the $\mathrm{PVH}$ and decreases UCP1 expression (279-282). Along the same lines, orexin-A (see below) administration within the PVH does not affect UCP1 expression in BAT (283). These data contrast with evidence showing that SNS activity, UCP1 mRNA expression, or temperature in interscapular BAT is increased following administration of several agents such as CRH (284), hydroxybutyrate (237), glutamate (285), norepinephrine, serotonin and tryptophan (238), cholecystokinin (CCK) (286), brain-derived neurotrophic factor (BDNF) (287), histamine (288), urocortin (UCN) (289), cocaine- and amphetamine-regulated transcript (CART) (282,290), and PGE $_{2}$ (291).

From an anatomical point of view, there are studies demonstrating that the PVH contains a large number of melanocortin-4 receptor (MC4R)-expressing neurons that project to BAT. Thus, theoretically, activation of those neurons would produce both anorexia and increased BAT thermogenesis via SNS innervation through neurons in the $\operatorname{rRPa}(279,280,292-294)$. Nevertheless, this is again a controversial issue. Acute administration of the MC4R agonist melanotan II (MTII) induces short-term increases in BAT temperature (294). Genetic ablation of MC4R induces an obese phenotype, and restoration of MC4R specifically in the $\mathrm{PVH}$ prevents obesity by normalizing the effects of melanocortins on food intake; notably, the reduced energy expenditure was not rescued, suggesting that the $\mathrm{PVH}$ is not involved in mediating the effects of melanocortins on energy expenditure (295). In contrast, other authors demonstrated that melanocortins in the PVH increase thermogenesis in BAT $(294,296)$. The possible explanation for these conflicting data could be the presence of inhibitory MC4R presynaptic neurons, which are GABAergic inputs whose activation hinders the inhibition of thermogenesis by the PVH. Thus, although PVH involvement in the regulation of BAT function remains unclear, existing and emerging data suggest that the $\mathrm{PVH}$ exerts a negative regulation on BAT thermogenesis.

\section{The arcuate nucleus of the hypothalamus (ARC)}

The ARC is considered as a 'master control center of feeding', containing neural populations inducing orexigenic actions (NPY/AgRP) and also neural populations inducing anorexigenic actions ( $\alpha-\mathrm{MSH}$, the product of POMC, as well as CART) (255,297-302). However, there is evidence that ARC also regulates BAT thermogenesis. In this sense, it has been demonstrated that the ARC orexigenic population inhibits thermogenesis and that partial loss of AgRP/NPY neurons leads to a lean, hypophagic phenotype, also characterized by sympathetic activation of BAT $(303,304)$.

Similarly to the PVH, the main implication of the ARC in thermogenesis regulation is linked to the central melanocortin system. Thus, loss of function of the key players of this system, such as POMC and MC4R, has been reported to cause massive obesity in rodents and humans $(305,306)$. In this regard, MC4R deficiency has been shown to blunt the ability of leptin to increase UCP1 expression in BAT and WAT (307). Given that the ARC is the major site for regulation of physiological processes by leptin, the possible role of this nucleus in the integration of leptin actions on thermogenesis is also of interest. Upon activation by leptin, POMC neurons in ARC release the catabolic fragment $\alpha-M S H$ from nerve terminals to increase UCP1 expression in BAT (307). Recent data have demonstrated that leptin receptors in the ARC are necessary for leptin-induced increases in BAT sympathetic discharge; in keeping with this, deletion of leptin signaling in the ARC abolishes sympathetic activation to BAT (308).

The chemical signature of the ARC populations regulating BAT is controversial, and it seems that more than one neuronal type is taking part in this control. Mice lacking synaptic GABA release from RIP-Cre neurons in the ARC have reduced energy expenditure, become obese, and are extremely sensitive to HFD-induced obesity (309). In the same model, leptin's ability to stimulate thermogenesis, but not to reduce feeding, is markedly attenuated. Acute, selective activation of arcuate GABAergic RIP-Cre neurons, which monosynaptically innervate $\mathrm{PVH}$ neurons, rapidly stimulates brown fat and increases energy expenditure but does not affect feeding. Importantly, this response 
is dependent upon GABA release from RIP-Cre neurons. This evidence demonstrates that GABAergic RIP-Cre neurons in the ARC selectively drive energy expenditure, contribute to leptin's stimulatory effect on thermogenesis, and protect against dietinduced obesity (309).

Since it is known that thermogenesis can be induced by diet, it could be hypothesized that activation of leptin receptors in the ARC could be involved in diet-induced BAT activity. Although leptin levels are higher in obese subjects due to increased WAT mass, the leptin resistance in these patients likely avoids the capacity of leptin to activate GABAergic RIP-Cre neurons in the ARC, and thereby does not activate thermogenesis through $\mathrm{PVH}$ connections. On the other hand, mice lacking RIP-Cre neurons are extremely sensitive to diet-induced obesity due to a defect in diet-induced thermogenesis (290). However, other mechanisms involved in diet-induced BAT activation still remain unclear. Recent data using genetic mouse models of conditional creatine kinase knockout mouse also indicate that NPY reduction in the ARC is coupled to increased UCP1 expression in BAT, resulting in activation of thermogenesis, and suggesting that NPY in the ARC negatively regulates BAT function (310). The same authors recently reported the implication of Rho-kinase 1 (ROCK1) from ARC neuronal population in the regulation of BAT thermogenesis. ROCK regulates leptin action and body weight homeostasis, and genetic deficiency of ROCK1, in POMC and AgRP neurons, promotes obesity and decreased leptin sensitivity (311), also decreasing the effect of leptin on the activation of the thermogenic program. Finally, mice with an AgRP neuron-specific deletion of vesicular GABA transporter are lean, resistant to obesity, and show increased BAT activity (312).

\section{Others central factors influencing BAT thermogenesis: novel targets to combat obesity?}

\section{The VMH AMPK-SNS-BAT axis: a canonical regulator of energy balance}

Besides the classical neuropeptide-based theory for both feeding and energy expenditure control, recent data demonstrate that basic cellular sensors, such AMPK and the mechanistic target of rapamycin (mTOR), play a major role in the modulation of energy balance (300,313-317). At hypothalamic level, the AMPK pathway is a canonical route regulating energy homeostasis, by integrating peripheral signals, such as hormones and metabolites with hypothalamic networks. AMPK is a cellular gauge that is activated in conditions of low energy, increasing energy production and reducing energy-wasting $(300,313,314,316)$. AMPK is an important regulator of fatty acid biosynthesis, suppressing de novo lipogenesis by inactivation of acetyl-CoA carboxylase (ACC) by phosphorylating it $(300,314)$. AMPK also regulates neuropeptide expression in the ARC (318-320).

Current evidence from our group has linked hypothalamic AMPK with BAT thermogenesis through modulation of the SNS. Although the first evidence linking hypothalamic AMPK with energy balance was mainly focused on feeding (300,318-320), it has become evident that AMPK also modulates the other side of the balance, namely energy expenditure. Null mice of protein tyrosine phosphatase 1B (PTP1B, which acts as an inhibitor of both insulin and leptin receptor signaling) show decreased body weight and are resistant to diet-induced obesity, associated with decreased hypothalamic AMPK $\alpha_{2}$ activity and increased BAT thermogenesis (321). This led to the speculation that hypothalamic AMPK may control BAT thermogenesis through the SNS, although it was not shown by those authors. This relationship was further explored by our group, and we demonstrated that decreased AMPK activity, specifically within the VMH, activates BAT thermogenesis through increased SNS outflow $(127,241,252,308)$. Notably, this pathway, which was initially described for central effects of thyroid hormones on energy balance (127), is also shared by leptin (322), BMP8B (bone morphogenetic protein 8B) (241), estradiol (E2) (M.L., unpublished data), glucagon like peptide-1 (GLP-1) (R.N., unpublished data), and nicotine (252), which have led us to propose the VMH AMPK-SNS-BAT axis as a canonical mechanism modulating energy homeostasis (124), with possible implications in the treatment of obesity. This was demonstrated by using constitutive genetic activation of AMPK in the VMH which blocked the actions of the factors described above (127,241,252,322). Additional studies are ongoing to test whether other hypothalamic sensors, such as uncoupling protein 2 (UCP2) and mTOR (M.L., unpublished observations), are also involved in the modulation of BAT.

\section{Orexins}

Orexins (OX-A and OX-B), also named hypocretins, are produced in neurons located in the lateral hypothalamic area (LHA), the $\mathrm{DMH}$, and perifornical hypothalamus (323-325). It is known that activation of the LHA promotes BAT function (326). In keeping with this, orexins have important roles in energy balance and feeding (323-325,327), and compelling evidence derived from genetic mouse models has suggested that orexins promote energy expenditure $(328,329)$ through modulation of locomotor activity and BAT thermogenesis (330-332). In fact, recent data suggest that orexins are required for BAT development, differentiation, and function (330). Moreover, lack of orexin's action compromises energy balance, as demonstrated in orexin knockout mice, which are prone to diet-induced obesity, when compared with normal mice (330). In vitro data pointed to a direct effect of orexin on differentiation of new brown adipocytes $(330,333)$. Morphological data have also identified a role for orexin neurons in the regulation of BAT thermogenesis via the SNS, involving direct projection from the LHA to the $\mathrm{rRPa}$, that activates its efferents to premotor sympathetic neurons via a catecholaminergic mechanism (273,334-337). Consistent with this, central injection of OX-A or OX-B, activation of orexin neurons in the LHA, or specific administration of OX-A in the VMH or the rRPa increased BAT thermogenic activity (326,335-338). This effect can be reproduced by administration into the diagonal band of Broca (339). Of note, the thermogenic effect of OX-A displays a very precise anatomical pattern, since its administration into the PVH does not impact BAT (283). The relevance of the thermogenic effect of orexin remains inconclusive but it has been speculated that it may be acting as an adaptive response to stress (340).

A protective role in aging-decreased thermogenic capacity was also recently suggested for orexins (341). The aging process causes an increase in percent body fat, but the mechanism remains unclear. Current data from rodent experiments have shown that aging is associated with defective differentiation of BAT, alongside morphologic abnormalities and thermogenic dysfunction in rodents (341) and humans (47,342,343). In fact, interscapular brown tissue in aged mice is progressively populated by adipocytes, bearing white morphologic characteristics (341). Aged mice also fail to mobilize intracellular fuel reserves from brown adipocytes and exhibit deficiency in homeothermy. Of note, those effects are reversed by OX-A administration, while they are accelerated in mice in which OX-producing neurons were ablated (341). Further work will be required to address whether the orexin 
system may be targeted for intervention to reverse age-associated increase in fat mass. In this regard, aging is also associated with important changes such as leptin resistance, blunting normal central and peripheral functions of leptin $(344,345)$. Thus, restoration of leptin sensitivity during aging might be another possibility to increase BAT function and reduce the amount of fat. Also, ablation of the ghrelin receptor (growth hormone secretagogue receptor, GHS-R) in old mice increases energy expenditure and resting metabolic rate and prevents age-associated decline in UCP1 expression (346). These results suggest that the ghrelin/GHS-R system might also be of clinical relevance. Finally, reduced nuclear SIRT1 activity initiates age-related mitochondrial decline $(347,348)$, so it is also tempting to speculate that the reactivation of SIRT1 in old age might restore BAT activity.

\section{Bone morphogenetic proteins (BMPs)}

BMPs belong to the transforming growth factor superfamiliy and have been recently discovered to be key actors in the differentiation and development of BAT $(241,349)$. Recently, it has been discovered that BMP8B is expressed in BAT and also in the hypothalamus. Notably, central administration of BMP8B induces thermogenesis, and increased core temperature, leading to weight loss. In the $\mathrm{VMH}$, this action of BMP8B is AMPKdependent, and increases sympathetic outflow to BAT, without altering feeding behavior (241). This evidence, alongside our data showing that nicotine stimulates thermogenesis through the same mechanism $(252,253)$, indicates that this pathway may be a useful target for obesity treatment. Likewise, systemic administration of BMP7 reduces body weight gain at least in part due to induction of BAT-mediated energy expenditure (349). Stimulation of $\beta_{3}$-adrenoreceptors and BMP7 synergistically increase UCP1 expression in WAT, suggesting that BMP7 may increase the sensitivity of adipocytes to sympathetic tone, like BMP8B (350). Whether BMP7 actions are mediated by the VMH AMPKSNS-BAT axis remains unclear, but it is a possibility worth investigating. In this sense, BMP receptors are present in different hypothalamic regions involved in metabolic control (241). Thus, it seems that a cross-talk between BMP signals and SNS activation on peripheral and central levels may be a critical way to modulate global thermogenic capacity.

Besides its central action, BMP8B appears to be produced by mature brown adipocytes and its expression regulated by temperature and other metabolic cues, suggesting that it is under the control of central temperature sensing (241). By contrast, BMP7 is produced by the stromal vascular cells within the adipose tissue and may serve as a niche factor to drive the tissue-resident progenitors to differentiate into the brown lineage (350).

\section{Glucagon-like peptide 1}

Another recently reported factor that influences central regulation of BAT thermogenesis is GLP-1, which when directly administrated into the brain reduces body weight by increasing BAT thermogenesis, a process correlated with increased activity of sympathetic fibers innervating BAT (351). This finding suggests that increased BAT thermogenesis may be an additional mechanism in which pharmacological stimulation of GLP-1R controls energy balance $(351,352)$. However, the exact brain regions and pathways through which GLP-1 stimulates BAT activity are unreported, although evidence from our group indicates that this effect is mediated by modulation of AMPK in the VMH (R.N., unpublished data). Taking into account that long-acting GLP-1 agonists are now at the forefront in the clinical management of type 2 diabetes and have been shown also to decrease BMI, studies addressing and uncovering their effects on energy expenditure are eagerly awaited.

\section{Amylin}

Amylin is a pancreatic hormone that was recently shown to be involved in central regulation of thermogenesis (353-357). Its ICV administration reduces body weight and food intake and increases body temperature by inducing sympathetic activity to BAT. These effects are blocked by pharmacological antagonism of amylin receptors, supporting their implication in BAT thermogenesis activation (357). In line with these data, neuronal overexpression of the amylin receptor subunit, RAMP1 (receptor-activity modifying protein 1) leads to higher energy expenditure, as indicated by increased oxygen consumption, elevated body temperature, and higher sympathetic tone subserving BAT. Consistent with this, the nestin/hRAMP1 transgenic mice had elevated BAT mRNA levels of PGC1 $\alpha$, UCP1, and UCP3, which can all be reversed by chronic blockade of sympathetic signaling (356). These data have a potential clinical impact, since amylin and its analogs have recently emerged as potential antiobesity drugs. In particular, the demonstration that amylin can restore or enhance leptin sensitivity in obese patients has raised interest in the CNS-mediated physiological effects of amylin and its role in the pathogenesis of obesity (356-359). Pramlintide is the clinically available amylin analogue currently approved for the treatment of patients with type 1 diabetes mellitus or type 2 diabetes mellitus who have not achieved optimal glycemic control after insulin therapy. Used as an adjunct to lifestyle changes, this drug decreased food intake and body weight in obese individuals followed for 12 months (360). In another clinical study conducted in obese or overweight subjects, the combined treatment with leptin and amylin for 4 weeks caused more weight loss than in the individual treatment groups (361). Therefore, these findings support amylin as a promising antiobesity target, particularly for use in combinatorial therapy, a strategy that is now arising to maximize weight reduction $(359,362)$. Whatever the case, an exact knowledge of the molecular underpinnings modulating its actions will be essential to refine the design of further antiobesity therapies. Further work will be required to assess the exact brain populations and molecular mechanisms involved in the control of BAT activity by amylin. Investigating the role of AMPK-expressing neurons in the $\mathrm{VMH}$ is an interesting strategy.

\section{Summary and conclusions}

BAT is a key organ in the maintenance of temperature through dissipation of heat by mitochondrial uncoupling. Although the 'classical' central control of BAT function was mainly based on the modulation of sympathetic outflow, the molecular details of that interaction have remained elusive. Recent developments have demonstrated that 'traditional' hormones, such as leptin (308), thyroid hormones (127), estradiol (250,251) (M.L., unpublished observations), and GLP-1 (352) (R.N., unpublished observations), as well as 'new' peripheral molecules, such as amylin $(356,357,359)$, nesfatin-1 (363), cannabinoids $(364,365)$, irisin (84), FGF21 (196), BMP7 (349), and BMP8B (241), modulate BAT function by acting on several hypothalamic nuclei. Thus, AMPK in the VMH $(127,241,252,322)$, NPY neurons in the DMH (266), GABAergic neurons in the ARC (309), and orexin neurons in the LHA (328-331), among others, play a major and canonical role in the modulation of BAT thermogenesis. However, although the recent developments in this field have 
generated a lot of excitement, some doubt still exists with regard to the possibility of targeting BAT thermogenesis as a mechanism to treat obesity $(5,6,8,33,53)$. Novel techniques, such as optogenetics, will clarify with more detail the existing mechanisms controlling BAT activity. Additionally, it is likely that new circuits implicated in thermogenesis will be also identified. The use of state-of-the-art methods will give us valuable and accurate information regarding the molecular targets to stimulate thermogenesis. Although the existence of cold-sensitive neurons has been documented long ago, the recent characterization of temperature-sensitive receptors open up new avenues to uncover the neural mechanisms involved in adaptation to changes in environment. Additional work will be necessary to demonstrate if our current hope in mechanisms controlling thermogenesis will be of valuable clinical therapeutic application in the future.

Declaration of interest: The authors report no conflicts of interest.

This work has been funded from the European Community's Seventh Framework Programme (FP7/2007-2013) under grant agreement no. 281854 (the ObERStress European Research Council Project) (M.L.) and 245009 (the Neurofast project) (R.N., C.D., and M.L.); Xunta de Galicia (F.G.: 10PXIB208126PR, R.N.: EM 2012/039 and 2012-CP069, M.L.: 2012-CP070); Instituto de Salud Carlos III (ISCIII) (M.L.: PI12/01814); MINECO co-funded by the FEDER Program of EU (F.G.: BFU-2010-14968, R.N.: RyC2008-02219 and BFU2012-35255, C.D.: BFU2011-29102); The Frank Mohn foundation, Bergen (J.F.); The National Institutes of Health (K.R.: HL084207); and the American Diabetes Association (K.R.: 1-11-BS-127). CIBER de Fisiopatología de la Obesidad y Nutrición is an initiative of ISCIII. The funders had no role in study design, data collection and analysis, decision to publish, or preparation of the manuscript.

\section{References}

1. Lowell BB, Spiegelman BM. Towards a molecular understanding of adaptive thermogenesis. Nature. 2000;404:652-60.

2. Cannon B, Nedergaard J. Brown adipose tissue: function and physiological significance. Physiol Rev. 2004;84:277-359.

3. van Marken Lichtenbelt WD, Vanhommerig JW, Smulders NM, Drossaerts JM, Kemerink GJ, Bouvy ND, et al. Cold-activated brown adipose tissue in healthy men. N Engl J Med. 2009;360:1500-8.

4. Tran TT, Kahn CR. Transplantation of adipose tissue and stem cells: role in metabolism and disease. Nat Rev Endocrinol. 2010;6:195-213.

5. Whittle AJ, López M, Vidal-Puig A. Using brown adipose tissue to treat obesity - the central issue. Trends Mol Med. 2011;17:405-11.

6. Whittle A, Relat-Pardo J, Vidal-Puig A. Pharmacological strategies for targeting BAT thermogenesis. Trends Pharmacol Sci. 2013;34: 347-55.

7. Carobbio S, Rosen B, Vidal-Puig A. Adipogenesis: new insights into brown adipose tissue differentiation. J Mol Endocrinol. 2013;51: T75-85.

8. Villarroya F, Vidal-Puig A. Beyond the sympathetic tone: the new brown fat activators. Cell Metab. 2013;17:638-43.

9. Villarroya J, Cereijo R, Villarroya F. An endocrine role for brown adipose tissue? Am J Physiol Endocrinol Metab. 2013;305:E567-72.

10. Wu J, Cohen P, Spiegelman BM. Adaptive thermogenesis in adipocytes: is beige the new brown? Genes Dev. 2013;27:234-50.

11. Granneman JG. Norepinephrine infusions increase adenylate cyclase responsiveness in brown adipose tissue. J Pharmacol Exp Ther. 1988;245:1075-80.

12. Zingaretti MC, Crosta F, Vitali A, Guerrieri M, Frontini A, Cannon B, et al. The presence of UCP1 demonstrates that metabolically active adipose tissue in the neck of adult humans truly represents brown adipose tissue. FASEB J. 2009;23:3113-20.

13. Goossens GH. The role of adipose tissue dysfunction in the pathogenesis of obesity-related insulin resistance. Physiol Behav. 2008;94:206-18.
14. Timmons JA, Wennmalm K, Larsson O, Walden TB, Lassmann T, Petrovic N, et al. Myogenic gene expression signature establishes that brown and white adipocytes originate from distinct cell lineages. Proc Natl Acad Sci U S A. 2007;104:4401-6.

15. Seale P, Bjork B, Yang W, Kajimura S, Chin S, Kuang S, et al. PRDM16 controls a brown fat/skeletal muscle switch. Nature. 2008;454:961-7.

16. Tseng YH, Kokkotou E, Schulz TJ, Huang TL, Winnay JN, Taniguchi CM, et al. New role of bone morphogenetic protein 7 in brown adipogenesis and energy expenditure. Nature. 2008;454: $1000-4$.

17. Sharp LZ, Shinoda K, Ohno H, Scheel DW, Tomoda E, Ruiz L, et al. Human BAT possesses molecular signatures that resemble beige/brite cells. PLoS One. 2012;7:e49452.

18. Wu J, Bostrom P, Sparks LM, Ye L, Choi JH, Giang AH, et al. Beige adipocytes are a distinct type of thermogenic fat cell in mouse and human. Cell. 2012;150:366-76.

19. Jespersen NZ, Larsen TJ, Peijs L, Daugaard S, Homoe P, Loft A, et al. A classical brown adipose tissue mRNA signature partly overlaps with brite in the supraclavicular region of adult humans. Cell Metab. 2013;17:798-805.

20. Lee P, Werner CD, Kebebew E, Celi FS. Functional thermogenic beige adipogenesis is inducible in human neck fat. Int J Obes (Lond). 2014;38:170-6.

21. Lidell ME, Betz MJ, Dahlqvist LO, Heglind M, Elander L, Slawik M, et al. Evidence for two types of brown adipose tissue in humans. Nat Med. 2013;19:631-4.

22. Petrovic N, Walden TB, Shabalina IG, Timmons JA, Cannon B, Nedergaard J. Chronic peroxisome proliferator-activated receptor gamma (PPARgamma) activation of epididymally derived white adipocyte cultures reveals a population of thermogenically competent, UCP1-containing adipocytes molecularly distinct from classic brown adipocytes. J Biol Chem. 2010;285:7153-64.

23. Shabalina IG, Petrovic N, de Jong JM, Kalinovich AV, Cannon B, Nedergaard J. UCP1 in brite/beige adipose tissue mitochondria is functionally thermogenic. Cell Rep. 2013;5:1196-203.

24. Walden TB, Hansen IR, Timmons JA, Cannon B, Nedergaard J. Recruited vs. nonrecruited molecular signatures of brown, "brite," and white adipose tissues. Am J Physiol Endocrinol Metab. 2012;302: E19-31.

25. Nedergaard J, Cannon B. UCP1 mRNA does not produce heat. Biochim Biophys Acta. 2013;1831:943-9.

26. Keipert S, Jastroch M. Brite/beige fat and UCP1 - is it thermogenesis? Biochim Biophys Acta. 2014 Feb 14. [Epub ahead of print].

27. Nedergaard J, Lindberg O. The brown fat cell. Int Rev Cytol. 1982;74:187-286.

28. Nicholls DG. Hamster brown-adipose-tissue mitochondria. The control of respiration and the proton electrochemical potential gradient by possible physiological effectors of the proton conductance of the inner membrane. Eur J Biochem. 1974;49:573-83.

29. Heaton GM, Wagenvoord RJ, Kemp A Jr, Nicholls DG. Brown-adiposetissue mitochondria: photoaffinity labelling of the regulatory site of energy dissipation. Eur J Biochem. 1978;82:515-21.

30. Garlid KD, Jaburek M, Jezek P, Varecha M. How do uncoupling proteins uncouple? Biochim Biophys Acta. 2000;1459:383-9.

31. Jaburek M, Varecha M, Jezek P, Garlid KD. Alkylsulfonates as probes of uncoupling protein transport mechanism. Ion pair transport demonstrates that direct $\mathrm{H}(+)$ translocation by UCP1 is not necessary for uncoupling. J Biol Chem. 2001;276:31897-905.

32. van Marken Lichtenbelt WD, Schrauwen P. Implications of nonshivering thermogenesis for energy balance regulation in humans. Am J Physiol Regul Integr Comp Physiol. 2011;301:R285-96.

33. Cypess AM, Kahn CR. Brown fat as a therapy for obesity and diabetes. Curr Opin Endocrinol Diabetes Obes. 2010;17:143-9.

34. Cao W, Medvedev AV, Daniel KW, Collins S. beta-Adrenergic activation of p38 MAP kinase in adipocytes: cAMP induction of the uncoupling protein 1 (UCP1) gene requires p38 MAP kinase. J Biol Chem. 2001;276:27077-82.

35. Holm C, Fredrikson G, Cannon B, Belfrage P. Hormone-sensitive lipase in brown adipose tissue: identification and effect of cold exposure. Biosci Rep. 1987;7:897-904.

36. Shih MF, Taberner PV. Selective activation of brown adipocyte hormone-sensitive lipase and cAMP production in the mouse by beta 3-adrenoceptor agonists. Biochem Pharmacol. 1995;50: $601-8$.

37. Clifford GM, Londos C, Kraemer FB, Vernon RG, Yeaman SJ. Translocation of hormone-sensitive lipase and perilipin upon lipolytic stimulation of rat adipocytes. J Biol Chem. 2000;275:5011-15. 
38. Morimoto C, Kameda K, Tsujita T, Okuda H. Relationships between lipolysis induced by various lipolytic agents and hormone-sensitive lipase in rat fat cells. J Lipid Res. 2001;42:120-7.

39. Bukowiecki LJ, Geloen A, Collet AJ. Proliferation and differentiation of brown adipocytes from interstitial cells during cold acclimation. Am J Physiol. 1986;250:C880-7.

40. Bartelt A, Bruns OT, Reimer R, Hohenberg H, Ittrich H, Peldschus K, et al. Brown adipose tissue activity controls triglyceride clearance. Nat Med. 2011;17:200-5.

41. Guerra C, Navarro P, Valverde AM, Arribas M, Bruning J, Kozak LP, et al. Brown adipose tissue-specific insulin receptor knockout shows diabetic phenotype without insulin resistance. J Clin Invest. 2001, 108:1205-13.

42. Gunawardana SC, Piston DW. Reversal of type 1 diabetes in mice by brown adipose tissue transplant. Diabetes. 2012;61:674-82.

43. Meyer CW, Willershauser M, Jastroch M, Rourke BC, Fromme T, Oelkrug R, et al. Adaptive thermogenesis and thermal conductance in wild-type and UCP1-KO mice. Am J Physiol Regul Integr Comp Physiol. 2010;299:R1396-406.

44. Mercer SW, Trayhurn P. Effect of high fat diets on energy balance and thermogenesis in brown adipose tissue of lean and genetically obese ob/ob mice. J Nutr. 1987;117:2147-53.

45. Dong M, Yang X, Lim S, Cao Z, Honek J, Lu H, et al. Cold exposure promotes atherosclerotic plaque growth and instability via UCP1dependent lipolysis. Cell Metab. 2013;18:118-29.

46. Nedergaard J, Bengtsson T, Cannon B. Unexpected evidence for active brown adipose tissue in adult humans. Am J Physiol Endocrinol Metab. 2007;293:E444-52

47. Cypess AM, Lehman S, Williams G, Tal I, Rodman D, Goldfine AB, et al. Identification and importance of brown adipose tissue in adult humans. N Engl J Med. 2009;360:1509-17.

48. Virtanen KA, Lidell ME, Orava J, Heglind M, Westergren R, Niemi T, et al. Functional brown adipose tissue in healthy adults. N Engl J Med. 2009;360:1518-25

49. Ishibashi J, Seale P. Medicine. Beige can be slimming. Science 2010;328:1113-14

50. Aune UL, Ruiz L, Kajimura S. Isolation and differentiation of stromal vascular cells to beige/brite cells. J Vis Exp. 2013 Mar 28. doi: $10.3791 / 50191$

51. Nakamura Y, Sato T, Shiimura Y, Miura Y, Kojima M. FABP3 and brown adipocyte-characteristic mitochondrial fatty acid oxidation enzymes are induced in beige cells in a different pathway from UCP1. Biochem Biophys Res Commun. 2013;441:42-6.

52. Lee YK, Cowan CA. White to brite adipocyte transition and back again. Nat Cell Biol. 2013;15:568-9.

53. Whittle A, Vidal-Puig A. When BAT is lacking, WAT steps up. Cell Res 2013;23:868-9.

54. Spiegelman BM, Puigserver P, Wu Z. Regulation of adipogenesis and energy balance by PPARgamma and PGC-1. Int J Obes Relat Metab Disord. 2000;24(Suppl 4):S8-10.

55. Tiraby C, Tavernier G, Lefort C, Larrouy D, Bouillaud F, Ricquier D, et al. Acquirement of brown fat cell features by human white adipocytes. J Biol Chem. 2003;278:33370-6.

56. Uldry M, Yang W, St-Pierre J, Lin J, Seale P, Spiegelman BM. Complementary action of the PGC-1 coactivators in mitochondrial biogenesis and brown fat differentiation. Cell Metab. 2006;3:333-41.

57. Ohno H, Shinoda K, Spiegelman BM, Kajimura S. PPARgamma agonists induce a white-to-brown fat conversion through stabilization of PRDM16 protein. Cell Metab. 2012;15:395-404.

58. Qiang L, Wang L, Kon N, Zhao W, Lee S, Zhang Y, et al. Brown remodeling of white adipose tissue by SirT1-dependent deacetylation of Ppargamma. Cell. 2012;150:620-32.

59. Seale P, Kajimura S, Spiegelman BM. Transcriptional control of brown adipocyte development and physiological function-of mice and men. Genes Dev. 2009;23:788-97.

60. Seale P. Transcriptional control of brown adipocyte development and thermogenesis. Int J Obes (Lond). 2010;34(Suppl 1):S17-22.

61. Tontonoz P, Hu E, Graves RA, Budavari AI, Spiegelman BM. mPPAR gamma 2: tissue-specific regulator of an adipocyte enhancer. Genes Dev. 1994;8:1224-34.

62. Tontonoz P, Hu E, Spiegelman BM. Stimulation of adipogenesis in fibroblasts by PPAR gamma 2, a lipid-activated transcription factor. Cell. 1994;79:1147-56.

63. Medina-Gomez G, Virtue S, Lelliott C, Boiani R, Campbell M, Christodoulides $\mathrm{C}$, et al. The link between nutritional status and insulin sensitivity is dependent on the adipocyte-specific peroxisome proliferator-activated receptor-gamma2 isoform. Diabetes. 2005; 54:1706-16.
64. Medina-Gomez G, Gray S, Vidal-Puig A. Adipogenesis and lipotoxicity: role of peroxisome proliferator-activated receptor gamma (PPARgamma) and PPARgammacoactivator-1 (PGC1). Public Health Nutr. 2007;10:1132-7.

65. Wang F, Mullican SE, DiSpirito JR, Peed LC, Lazar MA. Lipoatrophy and severe metabolic disturbance in mice with fat-specific deletion of PPARgamma. Proc Natl Acad Sci U S A. 2013;110: 18656-61.

66. Kajimura S, Seale P, Tomaru T, Erdjument-Bromage H, Cooper MP, Ruas JL, et al. Regulation of the brown and white fat gene programs through a PRDM16/CtBP transcriptional complex. Genes Dev. 2008;22:1397-409.

67. Walden TB, Petrovic N, Nedergaard J. PPARalpha does not suppress muscle-associated gene expression in brown adipocytes but does influence expression of factors that fingerprint the brown adipocyte. Biochem Biophys Res Commun. 2010;397:146-51.

68. Puigserver P, Wu Z, Park CW, Graves R, Wright M, Spiegelman BM. A cold-inducible coactivator of nuclear receptors linked to adaptive thermogenesis. Cell. 1998;92:829-39.

69. Wu Z, Puigserver P, Andersson U, Zhang C, Adelmant G, Mootha V, et al. Mechanisms controlling mitochondrial biogenesis and respiration through the thermogenic coactivator PGC-1. Cell. 1999;98: 115-24.

70. Tontonoz P, Spiegelman BM. Fat and beyond: the diverse biology of PPARgamma. Annu Rev Biochem. 2008;77:289-312.

71. Fruhbeck G, Sesma P, Burrell MA. PRDM16: the interconvertible adipo-myocyte switch. Trends Cell Biol. 2009;19:141-6.

72. Fruhbeck G, Becerril S, Sainz N, Garrastachu P, Garcia-Velloso MJ. BAT: a new target for human obesity? Trends Pharmacol Sci. 2009;30:387-96.

73. Park KW, Halperin DS, Tontonoz P. Before they were fat: adipocyte progenitors. Cell Metab. 2008;8:454-7.

74. Seale P, Conroe HM, Estall J, Kajimura S, Frontini A, Ishibashi J, et al. Prdm16 determines the thermogenic program of subcutaneous white adipose tissue in mice. J Clin Invest. 2011;121:96-105.

75. Christian M, White R, Parker MG. Metabolic regulation by the nuclear receptor corepressor RIP140. Trends Endocrinol Metab. 2006;17: 243-50.

76. Leonardsson G, Steel JH, Christian M, Pocock V, Milligan S, Bell J, et al. Nuclear receptor corepressor RIP140 regulates fat accumulation. Proc Natl Acad Sci U S A. 2004;101:8437-42.

77. Christian M, Kiskinis E, Debevec D, Leonardsson G, White $R$ Parker MG. RIP140-targeted repression of gene expression in adipocytes. Mol Cell Biol. 2005;25:9383-91.

78. Powelka AM, Seth A, Virbasius JV, Kiskinis E, Nicoloro SM, Guilherme A, et al. Suppression of oxidative metabolism and mitochondrial biogenesis by the transcriptional corepressor RIP140 in mouse adipocytes. J Clin Invest. 2006;116:125-36.

79. Seth A, Steel JH, Nichol D, Pocock V, Kumaran MK, Fritah A, et al. The transcriptional corepressor RIP140 regulates oxidative metabolism in skeletal muscle. Cell Metab. 2007;6:236-45.

80. Wang L, Li Y, Hu P, Teng CT. PGC-1alpha induces dynamic protein interactions on the ERRalpha gene multi-hormone response element nucleosome in kidney cells. Biochem J. 2008;416:407-19.

81. Hallberg M, Morganstein DL, Kiskinis E, Shah K, Kralli A, Dilworth SM, et al. A functional interaction between RIP140 and PGC-1alpha regulates the expression of the lipid droplet protein CIDEA. Mol Cell Biol. 2008;28:6785-95.

82. Bostrom P, Wu J, Jedrychowski MP, Korde A, Ye L, Lo JC, et al. A PGC1alpha-dependent myokine that drives brown-fat-like development of white fat and thermogenesis. Nature. 2012;481:463-8.

83. Goto M, Terada S, Kato M, Katoh M, Yokozeki T, Tabata I, et al. cDNA Cloning and mRNA analysis of PGC-1 in epitrochlearis muscle in swimming-exercised rats. Biochem Biophys Res Commun. 2000; 274:350-4.

84. Baar K, Wende AR, Jones TE, Marison M, Nolte LA, Chen M, et al. Adaptations of skeletal muscle to exercise: rapid increase in the transcriptional coactivator PGC-1. FASEB J. 2002;16:1879-86.

85. Zhang Y, Li R, Meng Y, Li S, Donelan W, Zhao Y, et al. Irisin stimulates browning of white adipocytes through mitogen-activated protein kinase p38 MAP kinase and ERK MAP kinase signaling. Diabetes. 2014;63:514-25.

86. Lee P, Linderman JD, Smith S, Brychta RJ, Wang J, Idelson C, et al. Irisin and FGF21 are cold-induced endocrine activators of brown fat function in humans. Cell Metab. 2014;19:302-9.

87. Raschke S, Elsen M, Gassenhuber H, Sommerfeld M, Schwahn U, Brockmann B, et al. Evidence against a beneficial effect of irisin in humans. PLoS One. 2013;8:e73680. 
88. Pekkala S, Wiklund PK, Hulmi JJ, Ahtiainen JP, Horttanainen M, Pollanen E, et al. Are skeletal muscle FNDC5 gene expression and irisin release regulated by exercise and related to health? J Physiol. 2013;591:5393-400.

89. Roca-Rivada A, Castelao C, Senin LL, Landrove MO, Baltar J, Belen CA, et al. FNDC5/irisin is not only a myokine but also an adipokine. PLoS One. 2013;8:e60563.

90. Novelle MG, Contreras C, Romero-Pico A, López M, Diéguez C. Irisin, two years later. Int J Endocrinol. 2013;2013:746281.

91. McKemy DD, Neuhausser WM, Julius D. Identification of a cold receptor reveals a general role for TRP channels in thermosensation. Nature. 2002;416:52-8.

92. Peier AM, Moqrich A, Hergarden AC, Reeve AJ, Andersson DA, Story GM, et al. A TRP channel that senses cold stimuli and menthol. Cell. 2002;108:705-15.

93. Bautista DM, Siemens J, Glazer JM, Tsuruda PR, Basbaum AI, Stucky CL, et al. The menthol receptor TRPM8 is the principal detector of environmental cold. Nature. 2007;448:204-8.

94. Colburn RW, Lubin ML, Stone DJ Jr, Wang Y, Lawrence D, D'Andrea MR, et al. Attenuated cold sensitivity in TRPM8 null mice. Neuron. 2007;54:379-86.

95. Dhaka A, Murray AN, Mathur J, Earley TJ, Petrus MJ, Patapoutian A. TRPM8 is required for cold sensation in mice. Neuron. 2007;54:371-8.

96. Story GM, Peier AM, Reeve AJ, Eid SR, Mosbacher J, Hricik TR, et al. ANKTM1, a TRP-like channel expressed in nociceptive neurons, is activated by cold temperatures. Cell. 2003;112:819-29.

97. Bandell M, Story GM, Hwang SW, Viswanath V, Eid SR, Petrus MJ, et al. Noxious cold ion channel TRPA1 is activated by pungent compounds and bradykinin. Neuron. 2004;41:849-57.

98. Jordt SE, Bautista DM, Chuang HH, McKemy DD, Zygmunt PM, Hogestatt ED, et al. Mustard oils and cannabinoids excite sensory nerve fibres through the TRP channel ANKTM1. Nature. 2004;427:260-5.

99. Caterina MJ, Schumacher MA, Tominaga M, Rosen TA, Levine JD, Julius D. The capsaicin receptor: a heat-activated ion channel in the pain pathway. Nature. 1997;389:816-24.

100. Tominaga M, Caterina MJ, Malmberg AB, Rosen TA, Gilbert $H$ Skinner $\mathrm{K}$, et al. The cloned capsaicin receptor integrates multiple pain-producing stimuli. Neuron. 1998;21:531-43.

101. Guler AD, Lee $H$, Iida $T$, Shimizu I, Tominaga $M$, Caterina $M$. Heat-evoked activation of the ion channel, TRPV4. J Neurosci. 2002;22:6408-14.

102. Peier AM, Reeve AJ, Andersson DA, Moqrich A, Earley TJ, Hergarden AC, et al. A heat-sensitive TRP channel expressed in keratinocytes. Science. 2002;296:2046-9.

103. Smith GD, Gunthorpe MJ, Kelsell RE, Hayes PD, Reilly P, Facer P, et al. TRPV3 is a temperature-sensitive vanilloid receptor-like protein. Nature. 2002;418:186-90.

104. Watanabe H, Davis JB, Smart D, Jerman JC, Smith GD, Hayes P, et al. Activation of TRPV4 channels (hVRL-2/mTRP12) by phorbol derivatives. J Biol Chem. 2002;277:13569-77.

105. Xu H, Ramsey IS, Kotecha SA, Moran MM, Chong JA, Lawson D, et al. TRPV3 is a calcium-permeable temperature-sensitive cation channel. Nature. 2002;418:181-6.

106. Liedtke W, Choe Y, Marti-Renom MA, Bell AM, Denis CS, Sali A, et al. Vanilloid receptor-related osmotically activated channel (VR-OAC), a candidate vertebrate osmoreceptor. Cell. 2000;103: 525-35.

107. Strotmann R, Harteneck C, Nunnenmacher K, Schultz G, Plant TD. OTRPC4, a nonselective cation channel that confers sensitivity to extracellular osmolarity. Nat Cell Biol. 2000;2:695-702.

108. Ye L, Kleiner S, Wu J, Sah R, Gupta RK, Banks AS, et al. TRPV4 is a regulator of adipose oxidative metabolism, inflammation, and energy homeostasis. Cell. 2012;151:96-110.

109. Woudenberg-Vrenken TE, Bindels RJ, Hoenderop JG. The role of transient receptor potential channels in kidney disease. Nat Rev Nephrol. 2009;5:441-9.

110. Sinke AP, Deen PM. The physiological implication of novel proteins in systemic osmoregulation. FASEB J. 2011;25:3279-89.

111. Bordicchia M, Liu D, Amri EZ, Ailhaud G, Dessi-Fulgheri P, Zhang C, et al. Cardiac natriuretic peptides act via p38 MAPK to induce the brown fat thermogenic program in mouse and human adipocytes. J Clin Invest. 2012;122:1022-36.

112. Schwarz EJ, Reginato MJ, Shao D, Krakow SL, Lazar MA. Retinoic acid blocks adipogenesis by inhibiting C/EBPbeta-mediated transcription. Mol Cell Biol. 1997;17:1552-61.

113. Ziouzenkova O, Plutzky J. Retinoid metabolism and nuclear receptor responses: new insights into coordinated regulation of the PPAR-RXR complex. FEBS Lett. 2008;582:32-8.
114. Kane MA, Folias AE, Pingitore A, Perri M, Krois CR, Ryu JY, et al. CrbpI modulates glucose homeostasis and pancreas 9-cis-retinoic acid concentrations. Mol Cell Biol. 2011;31:3277-85.

115. Mercader J, Ribot J, Murano I, Felipe F, Cinti S, Bonet ML, et al. Remodeling of white adipose tissue after retinoic acid administration in mice. Endocrinology. 2006;147:5325-32.

116. Kiefer FW, Vernochet C, O’Brien P, Spoerl S, Brown JD, Nallamshetty $S$, et al. Retinaldehyde dehydrogenase 1 regulates a thermogenic program in white adipose tissue. Nat Med. 2012;18: 918-25.

117. Vegiopoulos A, Muller-Decker K, Strzoda D, Schmitt I, Chichelnitskiy E, Ostertag A, et al. Cyclooxygenase-2 controls energy homeostasis in mice by de novo recruitment of brown adipocytes. Science. 2010;328:1158-61.

118. Madsen L, Pedersen LM, Lillefosse HH, Fjaere E, Bronstad I, Hao Q et al. UCP1 induction during recruitment of brown adipocytes in white adipose tissue is dependent on cyclooxygenase activity. PLoS One. 2010;5:e11391.

119. Virtue S, Feldmann H, Christian M, Tan CY, Masoodi M, Dale M, et al. A new role for lipocalin prostaglandin $d$ synthase in the regulation of brown adipose tissue substrate utilization. Diabetes. 2012;61: 3139-47.

120. Gereben B, Zavacki AM, Ribich S, Kim BW, Huang SA, Simonides WS, et al. Cellular and molecular basis of deiodinase-regulated thyroid hormone signaling. Endocr Rev. 2008;29:898-938.

121. Cheng SY, Leonard JL, Davis PJ. Molecular aspects of thyroid hormone actions. Endocr Rev. 2010;31:139-70.

122. Brent GA. Mechanisms of thyroid hormone action. J Clin Invest. 2012;122:3035-43.

123. Warner A, Mittag J. Thyroid hormone and the central control of homeostasis. J Mol Endocrinol. 2012;49:R29-35.

124. López M, Alvarez CV, Nogueiras R, Diéguez C. Energy balance regulation by thyroid hormones at central level. Trends Mol Med. 2013;19:418-27.

125. López M, Seoane L, Señarís RM, Diéguez C. Prepro-orexin mRNA levels in the rat hypothalamus, and orexin receptors mRNA levels in the rat hypothalamus and adrenal gland are not influenced by the thyroid status. Neurosci Lett. 2001;300:171-5.

126. López M, Seoane L, Tovar S, Señarís RM, Diéguez C. Thyroid status regulates CART but not AgRP mRNA levels in the rat hypothalamus. Neuroreport. 2002;13:1775-9.

127. López M, Varela L, Vázquez MJ, Rodriguez-Cuenca S, González CR, Velagapudi VR, et al. Hypothalamic AMPK and fatty acid metabolism mediate thyroid regulation of energy balance. Nat Med. 2010;16:1001-8.

128. González CR, Martínez de Morentin PB, Martínez-Sanchez N, Gomez-Diaz C, Lage R, Varela L, et al. Hyperthyroidism differentially regulates neuropeptide S system in the rat brain. Brain Res. 2012; 1450:40-8.

129. Varela L, Martínez-Sanchez N, Gallego R, Vázquez MJ, Roa J, Gandara M, et al. Hypothalamic mTOR pathway mediates thyroid hormone-induced hyperphagia in hyperthyroidism. J Pathol. 2012; 227:209-22.

130. Silva JE. Thermogenic mechanisms and their hormonal regulation. Physiol Rev. 2006;86:435-64.

131. Dicker A, Raasmaja A, Cannon B, Nedergaard J. Increased alpha 1-adrenoceptor density in brown adipose tissue indicates recruitment drive in hypothyroid rats. Am J Physiol. 1992;263:E654-62.

132. Gordon CJ. Behavioral and autonomic thermoregulation in the rat following propylthiouracil-induced hypothyroidism. Pharmacol Biochem Behav. 1997;58:231-6.

133. Kim B. Thyroid hormone as a determinant of energy expenditure and the basal metabolic rate. Thyroid. 2008;18:141-4.

134. Sainsbury A, Zhang L. Role of the hypothalamus in the neuroendocrine regulation of body weight and composition during energy deficit. Obes Rev. 2012;13:234-57.

135. Bianco AC, Sheng XY, Silva JE. Triiodothyronine amplifies norepinephrine stimulation of uncoupling protein gene transcription by a mechanism not requiring protein synthesis. J Biol Chem. 1988;263:18168-75.

136. Martínez de Mena R, Scanlan TS, Obregon MJ. The T3 receptor beta1 isoform regulates $\mathrm{UCP} 1$ and $\mathrm{D} 2$ deiodinase in rat brown adipocytes. Endocrinology. 2010;151:5074-83.

137. Ribeiro MO, Bianco SD, Kaneshige M, Schultz JJ, Cheng SY, Bianco AC, et al. Expression of uncoupling protein 1 in mouse brown adipose tissue is thyroid hormone receptor-beta isoform specific and required for adaptive thermogenesis. Endocrinology. 2010;151: 432-40. 
138. Wikstrom L, Johansson C, Salto C, Barlow C, Campos BA, Baas $\mathrm{F}$, et al. Abnormal heart rate and body temperature in mice lacking thyroid hormone receptor alpha 1. EMBO J. 1998;17: 455-61.

139. Golozoubova V, Gullberg H, Matthias A, Cannon B, Vennstrom B, Nedergaard J. Depressed thermogenesis but competent brown adipose tissue recruitment in mice devoid of all hormone-binding thyroid hormone receptors. Mol Endocrinol. 2004;18:384-401.

140. Marrif H, Schifman A, Stepanyan Z, Gillis MA, Calderone A, Weiss RE et al. Temperature homeostasis in transgenic mice lacking thyroid hormone receptor-alpha gene products. Endocrinology. 2005;146: 2872-84

141. Sjogren M, Alkemade A, Mittag J, Nordstrom K, Katz A, Rozell B, et al. Hypermetabolism in mice caused by the central action of an unliganded thyroid hormone receptor alpha1. EMBO J. 2007;26: 4535-45.

142. Ramadan W, Marsili A, Larsen PR, Zavacki AM, Silva JE. Type-2 iodothyronine 5'deiodinase (D2) in skeletal muscle of C57Bl/6 mice. II. Evidence for a role of D2 in the hypermetabolism of thyroid hormone receptor alpha-deficient mice. Endocrinology. 2011;152: 3093-102.

143. Bianco AC, Silva JE. Optimal response of key enzymes and uncoupling protein to cold in BAT depends on local T3 generation. Am J Physiol. 1987;253:E255-63.

144. Bianco AC, Silva JE. Intracellular conversion of thyroxine to triiodothyronine is required for the optimal thermogenic function of brown adipose tissue. J Clin Invest. 1987;79:295-300.

145. Bianco AC, Silva JE. Nuclear 3,5,3'-triiodothyronine (T3) in brown adipose tissue: receptor occupancy and sources of T3 as determined by in vivo techniques. Endocrinology. 1987;120:55-62.

146. Bianco AC, Silva JE. Cold exposure rapidly induces virtual saturation of brown adipose tissue nuclear T3 receptors. Am J Physiol. 1988;255:E496-503.

147. de Jesus LA, Carvalho SD, Ribeiro MO, Schneider M, Kim SW, Harney JW, et al. The type 2 iodothyronine deiodinase is essential for adaptive thermogenesis in brown adipose tissue. J Clin Invest. 2001;108:1379-85.

148. Christoffolete MA, Linardi CC, de Jesus L, Ebina KN, Carvalho SD, Ribeiro MO, et al. Mice with targeted disruption of the Dio2 gene have cold-induced overexpression of the uncoupling protein 1 gene but fail to increase brown adipose tissue lipogenesis and adaptive thermogenesis. Diabetes. 2004;53:577-84.

149. Castillo M, Hall JA, Correa-Medina M, Ueta C, Kang HW, Cohen DE, et al. Disruption of thyroid hormone activation in type 2 deiodinase knockout mice causes obesity with glucose intolerance and liver steatosis only at thermoneutrality. Diabetes. 2011; 60:1082-9.

150. Skarulis MC, Celi FS, Mueller E, Zemskova M, Malek R, Hugendubler $\mathrm{L}$, et al. Thyroid hormone induced brown adipose tissue and amelioration of diabetes in a patient with extreme insulin resistance. J Clin Endocrinol Metab. 2010;95:256-62.

151. Casanueva FF, Diéguez C. Neuroendocrine regulation and actions of leptin. Front Neuroendocrinol. 1999;20:317-63.

152. Ahima RS, Flier JS. Leptin. Annu Rev Physiol. 2000;62:413-37.

153. Friedman JM. The function of leptin in nutrition, weight, and physiology. Nutr Rev. 2002;60:S1-14.

154. Flier JS. Obesity wars: molecular progress confronts an expanding epidemic. Cell. 2004;116:337-50.

155. Friedman JM. Leptin at $14 \mathrm{y}$ of age: an ongoing story. Am J Clin Nutr. 2009;89:973S-9S.

156. Haynes WG, Morgan DA, Walsh SA, Mark AL, Sivitz WI. Receptormediated regional sympathetic nerve activation by leptin. J Clin Invest. 1997;100:270-8.

157. Ueno N, Oh-ishi S, Segawa M, Nishida M, Fukuwatari Y, Kizaki T, et al. Effect of age on brown adipose tissue activity in the obese (ob/ob) mouse. Mech Ageing Dev. 1998;100:67-76.

158. Commins SP, Watson PM, Levin N, Beiler RJ, Gettys TW. Central leptin regulates the UCP1 and ob genes in brown and white adipose tissue via different beta-adrenoceptor subtypes. J Biol Chem. 2000; 275:33059-67.

159. Cowley MA, Smart JL, Rubinstein M, Cerdan MG, Diano S, Horvath TL, et al. Leptin activates anorexigenic POMC neurons through a neural network in the arcuate nucleus. Nature. 2001; 411:480-4.

160. Storlien LH, James DE, Burleigh KM, Chisholm DJ, Kraegen EW. Fat feeding causes widespread in vivo insulin resistance, decreased energy expenditure, and obesity in rats. Am J Physiol. 1986;251: E576-83.
161. Smith DM, Bloom SR, Sugden MC, Holness MJ. Glucose transporter expression and glucose utilization in skeletal muscle and brown adipose tissue during starvation and re-feeding. Biochem J. 1992; 282(Pt 1):231-5.

162. Sugden MC, Holness MJ. Physiological modulation of the uptake and fate of glucose in brown adipose tissue. Biochem J. 1993; 295(Pt 1):171-6.

163. Vallerand AL, Lupien J, Bukowiecki LJ. Interactions of cold exposure and starvation on glucose tolerance and insulin response. Am J Physiol. 1983;245:E575-81.

164. Rahmouni K, Morgan DA, Morgan GM, Liu X, Sigmund CD, Mark AL et al. Hypothalamic PI3K and MAPK differentially mediate regional sympathetic activation to insulin. J Clin Invest. 2004;114:652-8.

165. Orava J, Nuutila P, Lidell ME, Oikonen V, Noponen T, Viljanen T, et al. Different metabolic responses of human brown adipose tissue to activation by cold and insulin. Cell Metab. 2011;14:272-9.

166. Ortega-Molina A, Efeyan A, López-Guadamillas E, Munoz-Martin M, Gomez-López G, Canamero M, et al. Pten positively regulates brown adipose function, energy expenditure, and longevity. Cell Metab. 2012;15:382-94.

167. Hu E, Liang P, Spiegelman BM. AdipoQ is a novel adipose-specific gene dysregulated in obesity. J Biol Chem. 1996;271:10697-703.

168. Tsao TS, Lodish HF, Fruebis J. ACRP30, a new hormone controlling fat and glucose metabolism. Eur J Pharmacol. 2002;440:213-21.

169. Berg AH, Combs TP, Du X, Brownlee M, Scherer PE. The adipocytesecreted protein Acrp30 enhances hepatic insulin action. Nat Med. 2001;7:947-53.

170. Berg AH, Combs TP, Scherer PE. ACRP30/adiponectin: an adipokine regulating glucose and lipid metabolism. Trends Endocrinol Metab. 2002;13:84-9.

171. Caminos JE, Nogueiras R, Gallego R, Bravo S, Tovar S, Garcia-Caballero T, et al. Expression and regulation of adiponectin and receptor in human and rat placenta. J Clin Endocrinol Metab. 2005;90:4276-86.

172. Pineiro R, Iglesias MJ, Gallego R, Raghay K, Eiras S, Rubio J, et al. Adiponectin is synthesized and secreted by human and murine cardiomyocytes. FEBS Lett. 2005;579:5163-9.

173. Yamauchi T, Kamon J, Waki H, Terauchi Y, Kubota N, Hara K, et al. The fat-derived hormone adiponectin reverses insulin resistance associated with both lipoatrophy and obesity. Nat Med. 2001;7:941-6.

174. Kubota N, Yano W, Kubota T, Yamauchi T, Itoh S, Kumagai H, et al. Adiponectin stimulates AMP-activated protein kinase in the hypothalamus and increases food intake. Cell Metab. 2007;6:55-68.

175. Guillod-Maximin E, Roy AF, Vacher CM, Aubourg A, Bailleux V, Lorsignol A, et al. Adiponectin receptors are expressed in hypothalamus and colocalized with proopiomelanocortin and neuropeptide $\mathrm{Y}$ in rodent arcuate neurons. J Endocrinol. 2009;200:93-105.

176. Wen JP, Liu CE, Hu YT, Chen G, Lin LX. Globular adiponectin regulates energy homeostasis through AMP-activated protein kinaseacetyl-CoA carboxylase (AMPK/ACC) pathway in the hypothalamus. Mol Cell Biochem. 2010;344:109-15.

177. Qiao L, Kinney B, Schaack J, Shao J. Adiponectin inhibits lipolysis in mouse adipocytes. Diabetes. 2011;60:1519-27.

178. Kajimura D, Lee HW, Riley KJ, Arteaga-Solis E, Ferron M, Zhou B, et al. Adiponectin regulates bone mass via opposite central and peripheral mechanisms through FoxO1. Cell Metab. 2013;17:901-15.

179. Qiao L, Yoo HS, Bosco C, Lee B, Feng GS, Schaack J, et al. Adiponectin reduces thermogenesis by inhibiting brown adipose tissue activation in mice. Diabetologia. 2014;57:1027-36.

180. Steppan CM, Bailey ST, Bhat S, Brown EJ, Banerjee RR, Wright CM, et al. The hormone resistin links obesity to diabetes. Nature. 2001;409:307-12.

181. Nogueiras R, Novelle MG, Vázquez MJ, López M, Diéguez C. Resistin: regulation of food intake, glucose homeostasis and lipid metabolism. Endocr Dev. 2010;17:175-84.

182. Kosari S, Rathner JA, Badoer E. Central resistin enhances renal sympathetic nerve activity via phosphatidylinositol 3-kinase but reduces the activity to brown adipose tissue via extracellular signal-regulated kinase 1/2. J Neuroendocrinol. 2012;24:1432-9.

183. Kosari S, Camera DM, Hawley JA, Stebbing M, Badoer E. ERK1/2 in the brain mediates the effects of central resistin on reducing thermogenesis in brown adipose tissue. Int J Physiol Pathophysiol Pharmacol. 2013;5:184-9.

184. Tovar S, Nogueiras R, Tung LY, Castaneda TR, Vázquez MJ, Morris A et al. Central administration of resistin promotes short-term satiety in rats. Eur J Endocrinol. 2005;153:R1-5.

185. Vázquez MJ, González $\mathrm{CR}$, Varela L, Lage $\mathrm{R}$, Tovar $\mathrm{S}$, Sangiao-Alvarellos $\mathrm{S}$, et al. Central resistin regulates hypothalamic 
and peripheral lipid metabolism in a nutritional-dependent fashion. Endocrinology. 2008;149:4534-43.

186. Feldman D. Evidence that brown adipose tissue is a glucocorticoid target organ. Endocrinology. 1978;103:2091-7.

187. Viengchareun S, Penfornis P, Zennaro MC, Lombes M. Mineralocorticoid and glucocorticoid receptors inhibit UCP expression and function in brown adipocytes. Am J Physiol Endocrinol Metab. 2001;280:E640-9.

188. Soumano K, Desbiens S, Rabelo R, Bakopanos E, Camirand A, Silva JE. Glucocorticoids inhibit the transcriptional response of the uncoupling protein-1 gene to adrenergic stimulation in a brown adipose cell line. Mol Cell Endocrinol. 2000;165:7-15.

189. Zennaro MC, Le Menuet D, Viengchareun S, Walker F, Ricquier D, Lombes M. Hibernoma development in transgenic mice identifies brown adipose tissue as a novel target of aldosterone action. J Clin Invest. 1998;101:1254-60.

190. Penfornis P, Viengchareun S, Le Menuet D, Cluzeaud F, Zennaro MC, Lombes $\mathrm{M}$. The mineralocorticoid receptor mediates aldosteroneinduced differentiation of T37i cells into brown adipocytes. Am J Physiol Endocrinol Metab. 2000;279:E386-94.

191. Kharitonenkov A, Shiyanova TL, Koester A, Ford AM, Micanovic R, Galbreath EJ, et al. FGF-21 as a novel metabolic regulator. J Clin Invest. 2005;115:1627-35.

192. Badman MK, Pissios P, Kennedy AR, Koukos G, Flier JS, Maratos-Flier E. Hepatic fibroblast growth factor 21 is regulated by PPARalpha and is a key mediator of hepatic lipid metabolism in ketotic states. Cell Metab. 2007;5:426-37.

193. Inagaki T, Dutchak P, Zhao G, Ding X, Gautron L, Parameswara V, et al. Endocrine regulation of the fasting response by PPARalphamediated induction of fibroblast growth factor 21. Cell Metab. 2007;5:415-25.

194. Galman C, Lundasen T, Kharitonenkov A, Bina HA, Eriksson M, Hafstrom I, et al. The circulating metabolic regulator FGF21 is induced by prolonged fasting and PPARalpha activation in man. Cell Metab. $2008 ; 8: 169-74$.

195. Hondares E, Rosell M, González FJ, Giralt M, Iglesias R, Villarroya F. Hepatic FGF21 expression is induced at birth via PPARalpha in response to milk intake and contributes to thermogenic activation of neonatal brown fat. Cell Metab. 2010;11:206-12.

196. Hondares E, Iglesias R, Giralt A, González FJ, Giralt M, Mampel T, et al. Thermogenic activation induces FGF21 expression and release in brown adipose tissue. J Biol Chem. 2011;286:12983-90.

197. Fisher FM, Kleiner S, Douris N, Fox EC, Mepani RJ, Verdeguer F, et al. FGF21 regulates PGC-1alpha and browning of white adipose tissues in adaptive thermogenesis. Genes Dev. 2012;26:271-81.

198. Pols TW, Noriega LG, Nomura M, Auwerx J, Schoonjans K. The bile acid membrane receptor TGR5: a valuable metabolic target. Dig Dis. 2011;29:37-44.

199. Angelin B, Larsson TE, Rudling M. Circulating fibroblast growth factors as metabolic regulators-a critical appraisal. Cell Metab. 2012;16:693-705.

200. Sarruf DA, Thaler JP, Morton GJ, German J, Fischer JD, Ogimoto K, et al. Fibroblast growth factor 21 action in the brain increases energy expenditure and insulin sensitivity in obese rats. Diabetes. 2010; 59:1817-24.

201. Bookout AL, de Groot MH, Owen BM, Lee S, Gautron L, Lawrence HL, et al. FGF21 regulates metabolism and circadian behavior by acting on the nervous system. Nat Med. 2013;19: 1147-52.

202. Zhao Y, Dunbar JD, Kharitonenkov A. FGF21 as a therapeutic reagent. Adv Exp Med Biol. 2012;728:214-28.

203. Chambers JB, Williams TD, Nakamura A, Henderson RP, Overton JM, Rashotte ME. Cardiovascular and metabolic responses of hypertensive and normotensive rats to one week of cold exposure. Am J Physiol Regul Integr Comp Physiol. 2000;279:R1486-94.

204. Fregly MJ, Schechtman O. Direct blood pressure measurements in rats during abrupt exposure to, and removal from, cold air. Proc Soc Exp Biol Med. 1994;205:119-23.

205. Sun Z, Cade JR, Fregly MJ, Rowland NE. Effect of chronic treatment with propranolol on the cardiovascular responses to chronic cold exposure. Physiol Behav. 1997;62:379-84.

206. Moran MM, Roy RR, Wade CE, Corbin BJ, Grindeland RE. Size constraints of telemeters in rats. J Appl Physiol (1985). 1998;85: $1564-71$.

207. Stocks JM, Taylor NA, Tipton MJ, Greenleaf JE. Human physiological responses to cold exposure. Aviat Space Environ Med. 2004;75: 444-57.
208. Bianco AC, Maia AL, da Silva WS, Christoffolete MA. Adaptive activation of thyroid hormone and energy expenditure. Biosci Rep. 2005;25:191-208.

209. Laurberg P, Andersen S, Karmisholt J. Cold adaptation and thyroid hormone metabolism. Horm Metab Res. 2005;37:545-9.

210. Fuller CA, Horwitz BA, Horowitz JM. Shivering and nonshivering thermogenic responses of cold-exposed rats to hypothalamic warming. Am J Physiol. 1975;228:1519-24.

211. Satinoff E, Valentino D, Teitelbaum P. Thermoregulatory cold-defense deficits in rats with preoptic/anterior hypothalamic lesions. Brain Res Bull. 1976;1:553-65.

212. Imai-Matsumura $\mathrm{K}$, Matsumura $\mathrm{K}$, Nakayama $\mathrm{T}$. Involvement of ventromedial hypothalamus in brown adipose tissue thermogenesis induced by preoptic cooling in rats. Jpn J Physiol. 1984;34:939-43.

213. Scammell TE, Elmquist JK, Griffin JD, Saper CB. Ventromedial preoptic prostaglandin E2 activates fever-producing autonomic pathways. J Neurosci. 1996;16:6246-54.

214. Boulant JA. Role of the preoptic-anterior hypothalamus in thermoregulation and fever. Clin Infect Dis. 2000;31(Suppl 5):S157-61.

215. Bourova L, Pesanova Z, Novotny J, Bengtsson T, Svoboda P. Differentiation of cultured brown adipocytes is associated with a selective increase in the short variant of $\mathrm{g}(\mathrm{s})$ alpha protein. Evidence for higher functional activity of $\mathrm{g}(\mathrm{s})$ alphaS. Mol Cell Endocrinol. 2000;167: 23-31.

216. Guieu JD, Hardy JD. Effects of heating and cooling of the spinal cord on preoptic unit activity. J Appl Physiol. 1970;29:675-83.

217. Holt SJ, Wheal HV, York DA. Hypothalamic control of brown adipose tissue in Zucker lean and obese rats. Effect of electrical stimulation of the ventromedial nucleus and other hypothalamic centres. Brain Res. 1987; $405: 227-33$

218. Thornhill J, Halvorson I. Activation of shivering and non-shivering thermogenesis by electrical stimulation of the lateral and medial preoptic areas. Brain Res. 1994;656:367-74.

219. Boulant JA, Hardy JD. The effect of spinal and skin temperatures on the firing rate and thermosensitivity of preoptic neurones. J Physiol. 1974;240:639-60.

220. Hammel HT, Hardy JD, FUSCO MM. Thermoregulatory responses to hypothalamic cooling in unanesthetized dogs. Am J Physiol. 1960;198:481-6.

221. Nakamura K, Morrison SF. Preoptic mechanism for cold-defensive responses to skin cooling. J Physiol. 2008;586:2611-20.

222. Preston E, Triandafillou J, Haas N. Colchicine lesions of ventromedial hypothalamus: effects on regulatory thermogenesis in the rat. Pharmacol Biochem Behav. 1989;32:301-7.

223. Hogan S, Coscina DV, Himms-Hagen J. Brown adipose tissue of rats with obesity-inducing ventromedial hypothalamic lesions. Am J Physiol. 1982;243:E338-44.

224. Virtue S, Masoodi M, Velagapudi V, Tan CY, Dale M, Suorti T, et al. Lipocalin prostaglandin D synthase and PPARgamma2 coordinate to regulate carbohydrate and lipid metabolism in vivo. PLoS One. 2012;7:e39512.

225. Amir S, Schiavetto A. Injection of prostaglandin E2 into the anterior hypothalamic preoptic area activates brown adipose tissue thermogenesis in the rat. Brain Res. 1990;528:138-42.

226. Monda M, Sullo A, De Luca V, Viggiano A, Pellicano MP. Acute lesions of the ventromedial hypothalamus reduce sympathetic activation and thermogenic changes induced by PGE1. J Physiol Paris. 1997;91:285-90.

227. Steiner AA, Antunes-Rodrigues J, Branco LG. Role of preoptic second messenger systems (cAMP and cGMP) in the febrile response. Brain Res. 2002;944:135-45.

228. Cao WH, Fan W, Morrison SF. Medullary pathways mediating specific sympathetic responses to activation of dorsomedial hypothalamus. Neuroscience. 2004;126:229-40.

229. Perkins MN, Rothwell NJ, Stock MJ, Stone TW. Activation of brown adipose tissue thermogenesis by the ventromedial hypothalamus. Nature. 1981;289:401-2.

230. Yoshida T, Bray GA. Catecholamine turnover in rats with ventromedial hypothalamic lesions. Am J Physiol. 1984;246:R558-65.

231. Saito M, Minokoshi Y, Shimazu T. Ventromedial hypothalamic stimulation accelerates norepinephrine turnover in brown adipose tissue of rats. Life Sci. 1987;41:193-7.

232. Kelly L, Bielajew C. Ventromedial hypothalamic regulation of brown adipose tissue. Neuroreport. 1991;2:41-4.

233. Hugie T, Halvorson I, Thornhill J. Brown adipose tissue temperature responses following electrical stimulation of ventromedial hypothalamic and lateral preoptic areas or after norepinephrine infusion to Long Evans or Sprague-Dawley rats. Brain Res. 1992;575:57-62. 
234. Amir S. Intra-ventromedial hypothalamic injection of glutamate stimulates brown adipose tissue thermogenesis in the rat. Brain Res. 1990;511:341-4.

235. Amir S, Schiavetto A, Pollock R. Insulin co-injection suppresses the thermogenic response to glutamate microinjection into the $\mathrm{VMH}$ in rats. Brain Res. 1990;527:326-9.

236. Yoshimatsu H, Egawa M, Bray GA. Sympathetic nerve activity after discrete hypothalamic injections of L-glutamate. Brain Res. 1993; 601:121-8.

237. Sakaguchi T, Arase K, Bray GA. Effect of intrahypothalamic hydroxybutyrate on sympathetic firing rate. Metabolism. 1988;37:732-5.

238. Sakaguchi T, Bray GA. Effect of norepinephrine, serotonin and tryptophan on the firing rate of sympathetic nerves. Brain Res. 1989;492:271-80.

239. Bamshad M, Song CK, Bartness TJ. CNS origins of the sympathetic nervous system outflow to brown adipose tissue. Am J Physiol 1999;276:R1569-78.

240. Cano G, Passerin AM, Schiltz JC, Card JP, Morrison SF, Sved AF. Anatomical substrates for the central control of sympathetic outflow to interscapular adipose tissue during cold exposure. J Comp Neurol. 2003;460:303-26.

241. Whittle AJ, Carobbio S, Martins L, Slawik M, Hondares E, Vázquez MJ, et al. BMP8B increases brown adipose tissue thermogenesis through both central and peripheral actions. Cell. 2012;149:871-85.

242. Lindberg $\mathrm{D}$, Chen $\mathrm{P}, \mathrm{Li}$ C. Conditional viral tracing reveals that steroidogenic factor 1-positive neurons of the dorsomedial subdivision of the ventromedial hypothalamus project to autonomic centers of the hypothalamus and hindbrain. J Comp Neurol. 2013;521: 3167-90.

243. Morrison SF. RVLM and raphe differentially regulate sympathetic outflows to splanchnic and brown adipose tissue. Am J Physiol. 1999;276:R962-73.

244. Shibata M, Uno T, Hashimoto M. Neurons in the lower midbrain tonically inhibit non-shivering thermogenesis through their influence on inferior olivary neurons in anesthetized rats. J Thermal Biol. 1999;24:365-8.

245. Uno T, Shibata M. Role of inferior olive and thoracic IML neurons in nonshivering thermogenesis in rats. Am J Physiol Regul Integr Comp Physiol. 2001;280:R536-46.

246. Morrison SF, Madden CJ, Tupone D. Central neural regulation of brown adipose tissue thermogenesis and energy expenditure. Cell Metab. 2014 Mar 12. [Epub ahead of print].

247. Dimicco JA, Zaretsky DV. The dorsomedial hypothalamus: a new player in thermoregulation. Am J Physiol Regul Integr Comp Physiol. 2007;292:R47-63.

248. Kim KW, Zhao L, Donato J Jr, Kohno D, Xu Y, Elias CF, et al. Steroidogenic factor 1 directs programs regulating diet-induced thermogenesis and leptin action in the ventral medial hypothalamic nucleus. Proc Natl Acad Sci U S A. 2011;108:10673-8.

249. Jo YH. Endogenous BDNF regulates inhibitory synaptic transmission in the ventromedial nucleus of the hypothalamus. J Neurophysiol. 2012;107:42-9.

250. Musatov S, Chen W, Pfaff DW, Mobbs CV, Yang XJ, Clegg DJ, et al. Silencing of estrogen receptor alpha in the ventromedial nucleus of hypothalamus leads to metabolic syndrome. Proc Natl Acad Sci U S A. 2007;104:2501-6.

251. Xu Y, Nedungadi TP, Zhu L, Sobhani N, Irani BG, Davis KE, et al. Distinct hypothalamic neurons mediate estrogenic effects on energy homeostasis and reproduction. Cell Metab. 2011;14:453-65.

252. Martínez de Morentin PB, Whittle AJ, Ferno J, Nogueiras R, Diéguez C, Vidal-Puig A, et al. Nicotine induces negative energy balance through hypothalamic AMP-activated protein kinase. Diabetes. 2012;61:807-17.

253. Seoane-Collazo P, de Morentin PB, Ferno J, Diéguez C, Nogueiras R, López M. Nicotine improves obesity and hepatic steatosis and er stress in diet-induced obese male rats. Endocrinology. 2014;155: 1679-89.

254. Bernardis LL, Bellinger LL. The dorsomedial hypothalamic nucleus revisited: 1998 update. Proc Soc Exp Biol Med. 1998;218:284-306.

255. Bi S. Role of dorsomedial hypothalamic neuropeptide $\mathrm{Y}$ in energy homeostasis. Peptides. 2007;28:352-6.

256. Zaretskaia MV, Zaretsky DV, Shekhar A, Dimicco JA. Chemical stimulation of the dorsomedial hypothalamus evokes non-shivering thermogenesis in anesthetized rats. Brain Res. 2002;928:113-25.

257. Madden CJ, Morrison SF. Excitatory amino acid receptors in the dorsomedial hypothalamus mediate prostaglandin-evoked thermogenesis in brown adipose tissue. Am J Physiol Regul Integr Comp Physiol. 2004;286:R320-5.
258. Dimicco JA, Abshire VM. Evidence for GABAergic inhibition of a hypothalamic sympathoexcitatory mechanism in anesthetized rats. Brain Res. 1987;402:1-10.

259. Okamura H, Abitbol M, Julien JF, Dumas S, Berod A, Geffard M, et al Neurons containing messenger RNA encoding glutamate decarboxylase in rat hypothalamus demonstrated by in situ hybridization, with special emphasis on cell groups in medial preoptic area, anterior hypothalamic area and dorsomedial hypothalamic nucleus. Neuroscience. 1990;39:675-99.

260. Chen XM, Hosono T, Yoda T, Fukuda Y, Kanosue K. Efferent projection from the preoptic area for the control of non-shivering thermogenesis in rats. J Physiol. 1998;512(Pt 3):883-92.

261. Osaka T. Blockade of prostaglandin E2-induced thermogenesis by unilateral microinjection of GABAA receptor antagonist into the preoptic area. Brain Res. 2008;1230:107-14.

262. Cao WH, Morrison SF. Glutamate receptors in the raphe pallidus mediate brown adipose tissue thermogenesis evoked by activation of dorsomedial hypothalamic neurons. Neuropharmacology. 2006;51: 426-37.

263. Nakamura K, Matsumura K, Kobayashi S, Kaneko T. Sympathetic premotor neurons mediating thermoregulatory functions. Neurosci Res. 2005;51:1-8.

264. Enriori PJ, Sinnayah P, Simonds SE, Garcia RC, Cowley MA Leptin action in the dorsomedial hypothalamus increases sympathetic tone to brown adipose tissue in spite of systemic leptin resistance. J Neurosci. 2011;31:12189-97.

265. Zhang Y, Kerman IA, Laque A, Nguyen P, Faouzi M, Louis GW, et al Leptin-receptor-expressing neurons in the dorsomedial hypothalamus and median preoptic area regulate sympathetic brown adipose tissue circuits. J Neurosci. 2011;31:1873-84.

266. Chao PT, Yang L, Aja S, Moran TH, Bi S. Knockdown of NPY expression in the dorsomedial hypothalamus promotes development of brown adipocytes and prevents diet-induced obesity. Cell Metab. 2011;13:573-83.

267. Lee SJ, Verma S, Simonds SE, Kirigiti MA, Kievit P, Lindsley SR, et al Leptin stimulates neuropeptide $\mathrm{Y}$ and cocaine amphetamine-regulated transcript coexpressing neuronal activity in the dorsomedial hypothalamus in diet-induced obese mice. J Neurosci. 2013;33:15306-17.

268. Cerri M, Morrison SF. Corticotropin releasing factor increases in brown adipose tissue thermogenesis and heart rate through dorsomedial hypothalamus and medullary raphe pallidus. Neuroscience. 2006;140:711-21.

269. Zhang YH, Lu J, Elmquist JK, Saper CB. Lipopolysaccharide activates specific populations of hypothalamic and brainstem neurons that project to the spinal cord. J Neurosci. 2000;20:6578-86.

270. Horn T, Wilkinson MF, Landgraf R, Pittman QJ. Reduced febrile responses to pyrogens after lesions of the hypothalamic paraventricular nucleus. Am J Physiol. 1994;267:R323-8.

271. Caldeira JC, Franci CR, Pela IR. Bilateral lesion of hypothalamic paraventricular nucleus abolishes fever induced by endotoxin and bradykinin in rats. Ann N Y Acad Sci. 1998;856:294-7.

272. Lu J, Zhang YH, Chou TC, Gaus SE, Elmquist JK, Shiromani P, et al. Contrasting effects of ibotenate lesions of the paraventricular nucleus and subparaventricular zone on sleep-wake cycle and temperature regulation. J Neurosci. 2001;21:4864-74.

273. Oldfield BJ, Giles ME, Watson A, Anderson C, Colvill LM, McKinley MJ. The neurochemical characterisation of hypothalamic pathways projecting polysynaptically to brown adipose tissue in the rat. Neuroscience. 2002;110:515-26.

274. Bartness TJ, Vaughan $\mathrm{CH}$, Song CK. Sympathetic and sensory innervation of brown adipose tissue. Int J Obes (Lond). 2010; 34(Suppl 1):S36-42.

275. Vaughan $\mathrm{CH}$, Bartness TJ. Anterograde transneuronal viral tract tracing reveals central sensory circuits from brown fat and sensory denervation alters its thermogenic responses. Am J Physiol Regul Integr Comp Physiol. 2012;302:R1049-58.

276. Holt SJ, Wheal HV, York DA. Response of brown adipose tissue to electrical stimulation of hypothalamic centres in intact and adrenalectomized Zucker rats. Neurosci Lett. 1988;84:63-7.

277. Madden CJ, Morrison SF. Neurons in the paraventricular nucleus of the hypothalamus inhibit sympathetic outflow to brown adipose tissue. Am J Physiol Regul Integr Comp Physiol. 2009;296:R831-43.

278. Madden CJ, Tupone D, Cano G, Morrison SF. alpha2 Adrenergic receptor-mediated inhibition of thermogenesis. J Neurosci. 2013;33: 2017-28.

279. Egawa M, Yoshimatsu H, Bray GA. Neuropeptide Y suppresses sympathetic activity to interscapular brown adipose tissue in rats. Am J Physiol. 1991;260:R328-34. 
280. Billington CJ, Briggs JE, Harker S, Grace M, Levine AS. Neuropeptide $\mathrm{Y}$ in hypothalamic paraventricular nucleus: a center coordinating energy metabolism. Am J Physiol. 1994;266:R1765-70.

281. Kotz CM, Wang CF, Briggs JE, Levine AS, Billington CJ. Effect of NPY in the hypothalamic paraventricular nucleus on uncoupling proteins 1,2 , and 3 in the rat. Am J Physiol Regul Integr Comp Physiol. 2000;278:R494-8.

282. Wang C, Billington CJ, Levine AS, Kotz CM. Effect of CART in the hypothalamic paraventricular nucleus on feeding and uncoupling protein gene expression. Neuroreport. 2000;11:3251-5.

283. Russell SH, Small CJ, Sunter D, Morgan I, Dakin CL, Cohen MA, et al. Chronic intraparaventricular nuclear administration of orexin $\mathrm{A}$ in male rats does not alter thyroid axis or uncoupling protein-1 in brown adipose tissue. Regul Pept. 2002;104:61-8.

284. LeFeuvre RA, Rothwell NJ, Stock MJ. Activation of brown fat thermogenesis in response to central injection of corticotropin releasing hormone in the rat. Neuropharmacology. 1987;26:1217-21.

285. Amir S. Stimulation of the paraventricular nucleus with glutamate activates interscapular brown adipose tissue thermogenesis in rats. Brain Res. 1990;508:152-5.

286. Yoshimatsu H, Egawa M, Bray GA. Effects of cholecystokinin on sympathetic activity to interscapular brown adipose tissue. Brain Res. 1992;597:298-303

287. Wang C, Bomberg E, Billington C, Levine A, Kotz CM. Brain-derived neurotrophic factor in the hypothalamic paraventricular nucleus increases energy expenditure by elevating metabolic rate. Am J Physiol Regul Integr Comp Physiol. 2007;293:R992-1002.

288. Yasuda T, Masaki T, Sakata T, Yoshimatsu H. Hypothalamic neuronal histamine regulates sympathetic nerve activity and expression of uncoupling protein $1 \mathrm{mRNA}$ in brown adipose tissue in rats. Neuroscience. 2004;125:535-40.

289. Kotz CM, Wang C, Levine AS, Billington CJ. Urocortin in the hypothalamic PVN increases leptin and affects uncoupling proteins-1 and -3 in rats. Am J Physiol Regul Integr Comp Physiol. 2002;282: R546-51.

290. Kong W, Stanley S, Gardiner J, Abbott C, Murphy K, Seth A, et al. A role for arcuate cocaine and amphetamine-regulated transcript in hyperphagia, thermogenesis, and cold adaptation. FASEB J. 2003; $17: 1688-90$.

291. Bhatnagar S, Meaney MJ, Amir S. The effects of prostaglandin E2 injected into the paraventricular nucleus of the hypothalamus on brown adipose tissue thermogenesis in spontaneously hypertensive rats. Brain Res. 1993;613:285-7.

292. Kotz CM, Briggs JE, Grace MK, Levine AS, Billington CJ. Divergence of the feeding and thermogenic pathways influenced by NPY in the hypothalamic PVN of the rat. Am J Physiol. 1998;275:R471-7.

293. Fan W, Morrison SF, Cao WH, Yu P. Thermogenesis activated by central melanocortin signaling is dependent on neurons in the rostral raphe pallidus (rRPa) area. Brain Res. 2007;1179:61-9.

294. Song CK, Vaughan CH, Keen-Rhinehart E, Harris RB, Richard D, Bartness TJ. Melanocortin-4 receptor mRNA expressed in sympathetic outflow neurons to brown adipose tissue: neuroanatomical and functional evidence. Am J Physiol Regul Integr Comp Physiol. 2008; 295:R417-28.

295. Balthasar N, Dalgaard LT, Lee CE, Yu J, Funahashi H, Williams T, et al. Divergence of melanocortin pathways in the control of food intake and energy expenditure. Cell. 2005;123:493-505.

296. Skibicka KP, Grill HJ. Hypothalamic and hindbrain melanocortin receptors contribute to the feeding, thermogenic, and cardiovascular action of melanocortins. Endocrinology. 2009;150:5351-61.

297. Elmquist JK, Coppari R, Balthasar N, Ichinose M, Lowell BB. Identifying hypothalamic pathways controlling food intake, body weight, and glucose homeostasis. J Comp Neurol. 2005;493:63-71.

298. López M, Tovar S, Vázquez MJ, Williams LM, Diéguez C. Peripheral tissue-brain interactions in the regulation of food intake. Proc Nutr Soc. 2007;66:131-55.

299. Abizaid A, Horvath TL. Brain circuits regulating energy homeostasis. Regul Pept. 2008;149:3-10.

300. Lage R, Diéguez C, Vidal-Puig A, López M. AMPK: a metabolic gauge regulating whole-body energy homeostasis. Trends Mol Med. 2008; 14:539-49.

301. Kleinridders A, Konner AC, Bruning JC. CNS-targets in control of energy and glucose homeostasis. Curr Opin Pharmacol. 2009;9: 794-804.

302. Diéguez C, Vázquez MJ, Romero A, López $M$, Nogueiras R. Hypothalamic control of lipid metabolism: focus on leptin, ghrelin and melanocortins. Neuroendocrinology. 2011;94:1-11.
303. Bewick GA, Gardiner JV, Dhillo WS, Kent AS, White NE, Webster Z, et al. Post-embryonic ablation of AgRP neurons in mice leads to a lean, hypophagic phenotype. FASEB J. 2005;19:1680-2.

304. Shi YC, Lau J, Lin Z, Zhang H, Zhai L, Sperk G, et al. Arcuate NPY controls sympathetic output and BAT function via a relay of tyrosine hydroxylase neurons in the PVN. Cell Metab. 2013;17: 236-48.

305. Butler AA, Cone RD. The melanocortin receptors: lessons from knockout models. Neuropeptides. 2002;36:77-84.

306. Farooqi S, O'Rahilly S. Genetics of obesity in humans. Endocr Rev. 2006;27:710-18.

307. Zhang Y, Kilroy GE, Henagan TM, Prpic-Uhing V, Richards WG, Bannon AW, et al. Targeted deletion of melanocortin receptor subtypes 3 and 4, but not CART, alters nutrient partitioning and compromises behavioral and metabolic responses to leptin. FASEB J. 2005;19: 1482-91.

308. Harlan SM, Morgan DA, Agassandian K, Guo DF, Cassell MD, Sigmund CD, et al. Ablation of the leptin receptor in the hypothalamic arcuate nucleus abrogates leptin-induced sympathetic activation. Circ Res. 2011;108:808-12.

309. Kong D, Tong Q, Ye C, Koda S, Fuller PM, Krashes MJ, et al. GABAergic RIP-Cre neurons in the arcuate nucleus selectively regulate energy expenditure. Cell. 2012;151:645-57.

310. Van der Zee CE. Hypothalamic plasticity of neuropeptide $Y$ is lacking in brain-type creatine kinase double knockout mice with defective thermoregulation. Eur J Pharmacol. 2013;719:137-44.

311. Huang H, Kong D, Byun KH, Ye C, Koda S, Lee DH, et al. Rho-kinase regulates energy balance by targeting hypothalamic leptin receptor signaling. Nat Neurosci. 2012;15:1391-8.

312. Tong Q, Ye CP, Jones JE, Elmquist JK, Lowell BB. Synaptic release of GABA by AgRP neurons is required for normal regulation of energy balance. Nat Neurosci. 2008;11:998-1000.

313. Hardie DG, Carling D. The AMP-activated protein kinase-fuel gauge of the mammalian cell? Eur J Biochem. 1997;246:259-73.

314. Kahn BB, Alquier T, Carling D, Hardie DG. AMP-activated protein kinase: ancient energy gauge provides clues to modern understanding of metabolism. Cell Metab. 2005;1:15-25.

315. Woods SC, Seeley RJ, Cota D. Regulation of food intake through hypothalamic signaling networks involving mTOR. Annu Rev Nutr. 2008;28:295-311.

316. Blanco Martínez de Morentin P, González CR, Saha AK, Martins L, Diéguez C, Vidal-Puig A, et al. Hypothalamic AMP-activated protein kinase as a mediator of whole body energy balance. Rev Endocr Metab Disord. 2011;12:127-40.

317. Martínez de Morentin PB, Martínez-Sanchez N, Roa J, Ferno J Nogueiras R, Tena-Sempere M, et al. Hypothalamic mTOR: the rookie energy sensor. Curr Mol Med. 2014;14:3-21.

318. Minokoshi Y, Alquier T, Furukawa N, Kim YB, Lee A, Xue B, et al. AMP-kinase regulates food intake by responding to hormonal and nutrient signals in the hypothalamus. Nature. 2004;428: 569-74.

319. López M, Lage R, Saha AK, Perez-Tilve D, Vázquez MJ, Varela L, et al. Hypothalamic fatty acid metabolism mediates the orexigenic action of ghrelin. Cell Metab. 2008;7:389-99.

320. Andrews ZB, Liu ZW, Wallingford N, Erion DM, Borok E, Friedman JM, et al. UCP2 mediates ghrelin's action on NPY/AgRP neurons by lowering free radicals. Nature. 2008;454:846-51.

321. Xue B, Pulinilkunnil T, Murano I, Bence KK, He H, Minokoshi Y, et al Neuronal protein tyrosine phosphatase $1 \mathrm{~B}$ deficiency results in inhibition of hypothalamic AMPK and isoform-specific activation of AMPK in peripheral tissues. Mol Cell Biol. 2009;29:4563-73.

322. Tanida M, Yamamoto N, Shibamoto T, Rahmouni K. Involvement of hypothalamic AMP-activated protein kinase in leptin-induced sympathetic nerve activation. PLoS One. 2013;8:e56660.

323. Sakurai T, Amemiya A, Ishii M, Matsuzaki I, Chemelli RM, Tanaka H, et al. Orexins and orexin receptors: a family of hypothalamic neuropeptides and $G$ protein-coupled receptors that regulate feeding behavior. Cell. 1998;92:1.

324. de Lecea L, Kilduff TS, Peyron C, Gao X, Foye PE, Danielson PE, et al. The hypocretins: hypothalamus-specific peptides with neuroexcitatory activity. Proc Natl Acad Sci U S A. 1998;95:322-7.

325. López M, Tena-Sempere M, Diéguez C. Cross-talk between orexins (hypocretins) and the neuroendocrine axes (hypothalamic-pituitary axes). Front Neuroendocrinol. 2010;31:113-27.

326. Cerri M, Morrison SF. Activation of lateral hypothalamic neurons stimulates brown adipose tissue thermogenesis. Neuroscience. $2005 ; 135: 627-38$ 
327. López M, Nogueiras R, Tena-Sempere M, Diéguez C. Orexins (hypocretins) actions on the GHRH/somatostatin-GH axis. Acta Physiol (Oxf). 2010;198:325-34.

328. Hara J, Beuckmann CT, Nambu T, Willie JT, Chemelli RM, Sinton CM, et al. Genetic ablation of orexin neurons in mice results in narcolepsy, hypophagia, and obesity. Neuron. 2001;30:345-54.

329. Teske JA, Levine AS, Kuskowski M, Levine JA, Kotz CM. Elevated hypothalamic orexin signaling, sensitivity to orexin A, and spontaneous physical activity in obesity-resistant rats. Am J Physiol Regul Integr Comp Physiol. 2006;291:R889-99.

330. Sellayah D, Bharaj P, Sikder D. Orexin is required for brown adipose tissue development, differentiation, and function. Cell Metab. 2011;14:478-90.

331. Morrison SF, Madden CJ, Tupone D. Central control of brown adipose tissue thermogenesis. Front Endocrinol (Lausanne). 2012;3:pii: 00005.

332. Madden CJ, Tupone D, Morrison SF. Orexin modulates brown adipose tissue thermogenesis. Biomol Concepts. 2012;3:381-6.

333. Sellayah D, Sikder D. Orexin receptor-1 mediates brown fat developmental differentiation. Adipocyte. 2012;1:58-63.

334. Berthoud HR, Patterson LM, Sutton GM, Morrison C, Zheng H. Orexin inputs to caudal raphe neurons involved in thermal, cardiovascular, and gastrointestinal regulation. Histochem Cell Biol. 2005; 123:147-56.

335. Monda M, Viggiano AN, Viggiano A, Viggiano E, Lanza A, De Luca V. Hyperthermic reactions induced by orexin A: role of the ventromedial hypothalamus. Eur J Neurosci. 2005;22:1169-75.

336. Yasuda T, Masaki T, Kakuma T, Hara M, Nawata T, Katsuragi I, et al. Dual regulatory effects of orexins on sympathetic nerve activity innervating brown adipose tissue in rats. Endocrinology. 2005;146:2744-8.

337. Morrison SF, Madden CJ, Tupone D. An orexinergic projection from perifornical hypothalamus to raphe pallidus increases rat brown adipose tissue thermogenesis. Adipocyte. 2012;1:116-20.

338. Tupone D, Madden CJ, Cano G, Morrison SF. An orexinergic projection from perifornical hypothalamus to raphe pallidus increases rat brown adipose tissue thermogenesis. J Neurosci. 2011;31:15944-55.

339. Monda M, Viggiano A, Viggiano A, Fuccio F, De Luca V. Injection of orexin A into the diagonal band of Broca induces sympathetic and hyperthermic reactions. Brain Res. 2004;1018:265-71.

340. Zhang W, Sunanaga J, Takahashi Y, Mori T, Sakurai T, Kanmura Y, et al Orexin neurons are indispensable for stress-induced thermogenesis in mice. J Physiol. 2010;588:4117-29.

341. Sellayah D, Sikder D. Orexin restores aging-related brown adipose tissue dysfunction in male mice. Endocrinology. 2014;155:485-501.

342. Stefan N, Pfannenberg C, Haring HU. The importance of brown adipose tissue. N Engl J Med. 2009;361:416-17.

343. Saito M, Okamatsu-Ogura Y, Matsushita M, Watanabe K, Yoneshiro T, Nio-Kobayashi J, et al. High incidence of metabolically active brown adipose tissue in healthy adult humans: effects of cold exposure and adiposity. Diabetes. 2009;58:1526-31.

344. Carter S, Caron A, Richard D, Picard F. Role of leptin resistance in the development of obesity in older patients. Clin Interv Aging. 2013;8: 829-44.

345. Slawik M, Vidal-Puig AJ. Lipotoxicity, overnutrition and energy metabolism in aging. Ageing Res Rev. 2006;5:144-64.

346. Lin L, Saha PK, Ma X, Henshaw IO, Shao L, Chang BH, et al. Ablation of ghrelin receptor reduces adiposity and improves insulin sensitivity during aging by regulating fat metabolism in white and brown adipose tissues. Aging Cell. 2011;10:996-1010.

347. Nogueiras R, Habegger KM, Chaudhary N, Finan B, Banks AS Dietrich MO, et al. Sirtuin 1 and sirtuin 3: physiological modulators of metabolism. Physiol Rev. 2012;92:1479-514.
348. Christian BE, Shadel GS. Aging: it's SIRTainly possible to restore mitochondrial dysfunction. Curr Biol. 2014;24:R206-8.

349. Townsend KL, Suzuki R, Huang TL, Jing E, Schulz TJ, Lee K, et al. Bone morphogenetic protein 7 (BMP7) reverses obesity and regulates appetite through a central mTOR pathway. FASEB J. 2012;26: 2187-96.

350. Schulz TJ, Huang TL, Tran TT, Zhang H, Townsend KL, Shadrach JL et al. Identification of inducible brown adipocyte progenitors residing in skeletal muscle and white fat. Proc Natl Acad Sci U S A. 2011; 108:143-8

351. Lockie SH, Stefanidis A, Oldfield BJ, Perez-Tilve D. Brown adipose tissue thermogenesis in the resistance to and reversal of obesity: a potential new mechanism contributing to the metabolic benefits of proglucagon-derived peptides. Adipocyte. 2013;2:196-200.

352. Lockie SH, Heppner KM, Chaudhary N, Chabenne JR, Morgan DA Veyrat-Durebex C, et al. Direct control of brown adipose tissue thermogenesis by central nervous system glucagon-like peptide-1 receptor signaling. Diabetes. 2012;61:2753-62.

353. Ogawa A, Harris V, McCorkle SK, Unger RH, Luskey KL. Amylin secretion from the rat pancreas and its selective loss after streptozotocin treatment. J Clin Invest. 1990;85:973-6.

354. Roth JD, Hughes H, Kendall E, Baron AD, Anderson CM Antiobesity effects of the beta-cell hormone amylin in diet-induced obese rats: effects on food intake, body weight, composition, energy expenditure, and gene expression. Endocrinology. 2006;147: 5855-64.

355. Wielinga PY, Lowenstein C, Muff S, Munz M, Woods SC, Lutz TA Central amylin acts as an adiposity signal to control body weight and energy expenditure. Physiol Behav. 2010;101:45-52.

356. Zhang Z, Liu X, Morgan DA, Kuburas A, Thedens DR, Russo AF, et al Neuronal receptor activity-modifying protein 1 promotes energy expenditure in mice. Diabetes. 2011;60:1063-71.

357. Fernandes-Santos C, Zhang Z, Morgan DA, Guo DF, Russo AF Rahmouni K. Amylin acts in the central nervous system to increase sympathetic nerve activity. Endocrinology. 2013;154:2481-8.

358. Roth JD, Maier H, Chen S, Roland BL. Implications of amylin receptor agonism: integrated neurohormonal mechanisms and therapeutic applications. Arch Neurol. 2009;66:306-10.

359. López M, Nogueiras R. Firing up brown fat with brain amylin. Endocrinology. 2013;154:2263-5.

360. Smith SR, Aronne LJ, Burns CM, Kesty NC, Halseth AE, Weyer C. Sustained weight loss following 12-month pramlintide treatment as an adjunct to lifestyle intervention in obesity. Diabetes Care. 2008;31: 1816-23.

361. Ravussin E, Smith SR, Mitchell JA, Shringarpure R, Shan K, Maier H, et al. Enhanced weight loss with pramlintide/metreleptin: an integrated neurohormonal approach to obesity pharmacotherapy. Obesity (Silver Spring). 2009;17:1736-43.

362. Sadry SA, Drucker DJ. Emerging combinatorial hormone therapies for the treatment of obesity and T2DM. Nat Rev Endocrinol. 2013;9: 425-33.

363. Konczol K, Pinter O, Ferenczi S, Varga J, Kovacs K, Palkovits M, et al Nesfatin-1 exerts long-term effect on food intake and body temperature. Int J Obes (Lond). 2012;36:1514-21.

364. Cardinal P, Bellocchio L, Clark S, Cannich A, Klugmann M, Lutz B, et al. Hypothalamic CB1 cannabinoid receptors regulate energy balance in mice. Endocrinology. 2012;153:4136-43.

365. Jung KM, Clapper JR, Fu J, D’Agostino G, Guijarro A, Thongkham D, et al. 2-arachidonoylglycerol signaling in forebrain regulates systemic energy metabolism. Cell Metab. 2012;15:299-310. 